\title{
FORMAÇÃO E TRABALHO DE MESTRES E DOUTORES EM QUÍMICA TITULADOS NO BRASIL\#
}

\author{
Mauro Mendes Braga* \\ Departamento de Química, Instituto de Ciências Exatas, Universidade Federal de Minas Gerais, CP 702, 31270-901 \\ Belo Horizonte - MG \\ Sérgio de Azevedo \\ Universidade Estadual do Norte Fluminense, Av. Alberto Lamego, 2000, 28015-620 Campos - RJ
}

Recebido em 4/6/02

\begin{abstract}
MASTER AND DOCTORS OF CHEMISTRY FROM BRAZILIAN UNIVERSITIES: TRAINING AND JOBS. This article reports questions related to the training and jobs of chemistry graduates from Brazilian universities. It is focussed on academic and career paths and on relations between knowledge and work. The main questions addressed in this study were: what have been the paths since undergraduate education? what were graduates doing before their enrolment in master and doctoral programs? Which were their motivations for this? Where do graduates work now? How do they appraise some aspects of their graduate education? Did the degree enlarge their job opportunities and improve work quality? How much do they earn?
\end{abstract}

Keywords: chemistry graduates; evaluation; training and jobs.

\section{INTRODUÇÃO}

O início da atividade química no Brasil remonta aos tempos coloniais. Há registros de atividades nessa área desenvolvidas regularmente no país já na segunda metade do século XVIII, em especial nos setores da mineração e da agricultura, destacando-se como precursores os nomes do baiano Alexandre Rodrigues Ferreira e do mineiro Vicente Coelho de Seabra Silva Telles ${ }^{1}$.

Ainda no período colonial, cria-se, em 1812, a primeira instituição química do país, o Laboratório Químico Prático do Rio de Janeiro, de vida efêmera, mas seguido em 1818 pelo Laboratório Químico do Museu Nacional, de maior importância e vida bem mais duradoura $^{2}$. Duas das mais importantes personalidades políticas do país à época do Império demonstraram interesse e realizaram estudos e pesquisas em Química, em algum momento de suas vidas: José Bonifácio de Andrada e Silva e o imperador Dom Pedro II $^{3}$. A despeito da queixa de Mathias ${ }^{2}$, relativa ao descaso de diversos homens públicos do Império para com o desenvolvimento científico do país, citando especificamente o nome de José Bonifácio, é possível que o interesse desses dois expoentes tenha contribuído para a imigração de importantes químicos alemães, iniciando-se assim uma influência da escola alemã nessa área, que se estendeu por cerca de cem anos. Entre aqueles que mais contribuíram, nesse período, para o desenvolvimento dessa ciência no Brasil, devem ser mencionados os nomes de Theodor Péckolt, que reorganizou e dirigiu o Laboratório Químico do Museu Nacional, Wilhelm Michler, que foi professor da Escola Politécnica do Rio de Janeiro e F. Dafter, organizador da estação agronômica de Campinas ${ }^{4}$.

A Química no ensino superior, entretanto, durante muitos anos esteve restrita a atividades suplementares nos cursos médicos e nas escolas politécnicas. Somente em 1918, foi criado o Instituto de

*e-mail: braga@icex.ufmg.br

\# A CAPES e a UNESCO editaram recentemente o livro A pós-graduação no país: formação e trabalho de mestres e doutores no país, organizado por Jacques Velloso. Este artigo é a adaptação para Química Nova do cap. 11 deste livro.
Química do Rio de Janeiro, uma instituição de ensino superior especificamente destinada à formação de profissionais dessa área. Esse instituto foi concebido como um centro de pesquisa e ensino, propiciando uma formação com cunho rigorosamente científico ${ }^{4}$. A despeito desse propósito, no entanto, o instituto, assim como o Curso de Química da Escola Politécnica de São Paulo, criado no mesmo ano, limitaram-se a preparar mão-de-obra para a incipiente indústria nacional $^{2}$.

$\mathrm{O}$ ano de 1934 assiste a duas iniciativas fundamentais para o desenvolvimento da Química no Brasil. No Rio de Janeiro, funda-se a Escola Nacional de Química, inicialmente vinculada ao Departamento Nacional de Produção Mineral, órgão do Ministério da Agricultura àquela época, mas logo incorporada à Universidade do Brasil, em 1937. Essa escola orienta sua atuação preferencialmente para a formação de recursos humanos para a indústria aqui instalada, fornecendo inicialmente o diploma de Químico Industrial e, a partir de 1951, também o de Engenheiro Químico. Nesse mesmo ano, começa a atuar em cursos de pós-graduação - aperfeiçoamento, especialização e doutorado - e de extensão ${ }^{1}$.

Também em 1934, o governo de Armando Sales de Oliveira instala a Universidade de São Paulo, criando um departamento especificamente dedicado à Química, o Departamento de Química da Faculdade de Filosofia, Ciências e Letras. Para chefiar esse departamento, o governo de Armando Sales de Oliveira traz um experimentado professor alemão, docente da Universidade de Bonn, então com 43 anos: Heinrich Rheinboldt. A escolha não foi casual; pelo decreto de sua criação, a Universidade de São Paulo foi concebida como uma instituição capaz de “...promover, pela pesquisa, o progresso da ciência"4. Sendo assim, vários professores estrangeiros, de diferentes países, foram convidados para liderarem esse processo, em suas respectivas áreas do conhecimento, cuidando-se para priorizar, em cada campo, professores dos países considerados mais desenvolvidos cientificamente naquela área ${ }^{4}$.

A chegada de Rheinboldt à USP reforça a influência da escola alemã na atividade química desenvolvida no país, a qual já se consolidara, nas primeiras décadas do século XX, com a vinda de profissionais tais como Alfred Schaeffer, organizador do Laboratório de Análise do Estado, em Belo Horizonte, Otto Rothe, professor de Enge- 
nharia da Escola de Engenharia de Porto Alegre, e Erick Schrim ${ }^{4}$. Essa influência se estende também ao ensino superior, uma vez que Rheinboldt trouxe vários compatriotas, para auxiliá-lo na tarefa de construir aqui uma instituição de ensino e pesquisa em Química ${ }^{2,4}$. Sob a sua liderança, estabelece-se uma tradição de pesquisa científica no Departamento de Química da USP, fundamentada na tradição alemã, mesclando sólidos conteúdos experimentais com uma ampla formação de cultura geral, nas Ciências, nas Artes e na Filosofia ${ }^{2}$. Associada à pesquisa científica estava, de acordo com a tradição alemã, a formação pós-graduada. No final dos anos 60, quando se organiza o ensino de pós-graduação em nosso país - e o Departamento de Química da USP se separa da Faculdade de Filosofia, para constituir o Instituto de Química - já se havia formado cerca de 40 doutores neste departamento ${ }^{2}$.

A despeito das iniciativas da USP e de casos isolados em uma ou outra instituição de ensino superior, a pós-graduação, como parte integrante do sistema de formação no ensino superior brasileiro, só irá se institucionalizar com a reforma universitária de 1968, que estabelece as bases e os instrumentos para o seu desenvolvimento e a sua consolidação. A reforma, mesmo estabelecida de forma centralizadora e autoritária, em um momento de grande repressão política, que atingiu profundamente a instituição universitária ${ }^{5,6}$, acabou por incorporar várias propostas de modernização da universidade brasileira, que eram defendidas por jovens professores e inclusive algumas veiculadas pelo movimento estudantil. Entre estas, encontravam-se a indissociabilidade entre ensino e pesquisa, a extinção da cátedra, a criação dos departamentos, dos institutos básicos e do regime de dedicação exclusiva para os professores e a institucionalização da pós-graduação ${ }^{7}$. A partir daí, a pós-graduação e a pesquisa científica tornam-se metas do ensino superior brasileiro ${ }^{7}$, tendo sido estabelecidos diversos incentivos que, associados à atuação consistente da CAPES e do CNPq, possibilitaram o seu rápido desenvolvimento.

Na área de Química, o progresso foi acelerado. Em 1968 existiam apenas cinco cursos de pós-graduação funcionando no país: três na UFRJ, um na UFBA e um na UFMG, sendo que três deles só ofereciam o mestrado. Menos de cinco anos depois, em 1972, esse número havia triplicado, sendo que nove ofereciam mestrado e doutorado. Quando da primeira avaliação da $\mathrm{CAPES}^{8}$, em 1980, já existiam vinte e dois cursos de pós-graduação em Química no país, onze deles oferecendo mestrado e doutorado, que foram classificados da seguinte forma: mestrado - nove cursos A, sete cursos B, cinco cursos $\mathrm{C}$ e um curso D; doutorado - sete cursos A, dois cursos B, um curso $\mathrm{C}$ e um curso $\mathrm{E}^{9}$.

Na primeira avaliação bienal, referente aos anos 83-84, o quadro que se revelou na área de Química foi o descrito a seguir. No mestrado, onze cursos foram avaliados como A, oito, como B e dois, como C; no doutorado, oito cursos foram avaliados como A, dois, como B e um, como C. Dez anos depois, na avaliação referente ao biênio 94/95, os números foram ainda mais expressivos. No mestrado foram avaliados trinta e três cursos, sendo quatorze $A$, onze $B$ e três $C$, além de outros três que não foram avaliados por serem cursos novos. No doutorado, onze cursos foram classificados como A, quatro, como $\mathrm{B}$, dois, como $\mathrm{C}$, enquanto que oito não foram avaliados por serem cursos novos. Em termos de número de cursos, o crescimento foi de $50 \%$ no mestrado, e de quase $150 \%$ no doutorado, quando se comparam os dois biênios.

A Tabela 1 apresenta uma súmula dos indicadores da área nessas duas avaliações. Em dez anos, o número de titulados, no mestrado, cresceu $100 \%$ e, no doutorado, quase $300 \%$. O número de matrículas cresceu também quase $300 \%$, no doutorado, e cerca de $70 \%$, no mestrado. Os tempos médios de titulação foram reduzidos em pouco mais de $10 \%$, tanto no mestrado quanto no doutorado. O número de
Tabela 1. Comparação de alguns indicadores referentes a três avaliações da CAPES para a pós-graduação da área no país

\begin{tabular}{lrrr}
\hline & \multicolumn{3}{c}{ Período da avaliação } \\
\cline { 2 - 4 } Indicador & $\mathbf{8 3 / 8 4}$ & $\mathbf{9 4 / 9 5}$ & $\mathbf{9 6 / 9 7}$ \\
\hline Mestres titulados & 226 & 446 & 664 \\
Doutores titulados & 75 & 279 & 380 \\
Matrículas no mestrado & 599 & 1017 & - \\
Matrículas no doutorado & 276 & 1042 & - \\
Total de alunos matriculados & 875 & 2059 & 2981 \\
Tempo médio do mestrado, & 48 & 42 & 38 \\
em meses & & & \\
Tempo médio do doutorado, & 66 & 58 & 60 \\
em meses & & & \\
Publicações em periódicos & 119 & 299 & 399 \\
nacionais indexados & & & \\
Publicações em periódicos & 358 & 1024 & 1870 \\
internacionais indexados & & & \\
Doutores do corpo docente & 334 & 693 & - \\
permanente & & & \\
\hline
\end{tabular}

Fonte: Refs. 9 e 11

publicações nacionais cresceu em cerca de $100 \%$ e o de internacionais, quase $200 \%$. A razão entre o número de publicações internacionais e o número de publicações nacionais, que era de $3 / 1$, em 83/84, passou a ser, dez anos depois, de 3,5/1.

O fortalecimento da pesquisa científica e da pós-graduação na área de Química levou, ainda no final dos anos 70, à criação de uma sociedade científica nacional congregando os pesquisadores da área, a Sociedade Brasileira de Química, SBQ, cuja assembléia de fundação realizou-se em 1977. Já no ano seguinte, em janeiro de 1978, publicava-se o primeiro número da revista Química Nova, com tiragem de 1.500 exemplares ${ }^{10}$. Esse periódico, destinado a publicar artigos científicos e outras matérias de interesse dos químicos, apesar de inúmeros percalços e dificuldades, teve publicação regular ao longo de todo esse período. Em suas páginas vêm sendo, eventualmente, veiculados artigos apresentando dados sobre a evolução da pós-graduação em Química no Brasil ${ }^{11}$. Esses trabalhos, com raras exceções, são essencialmente descritivos, não se propondo a realizar uma análise comparativa e mais detalhada das informações que registram. Uma dessas raras exceções é o artigo publicado por Cagnin ${ }^{15}$, que discute o fomento à pesquisa científica no Brasil na perspectiva de uma ação articulada, visando o desenvolvimento tecnológico do país, em particular no que dizia respeito à área de química fina.

A avaliação da CAPES $^{8}$ referente ao biênio 96/97 se efetivou sob um novo padrão de classificação. A escala de avaliação passou a ser numérica, variando de um a sete, com o maior valor correspondendo a cursos de padrão internacional. Ademais, passou-se a avaliar os programas de pós-graduação, de tal forma que em uma mesma instituição os cursos de mestrado e doutorado são submetidos a uma avaliação conjunta, sendo que programas oferecendo apenas o mestrado podem receber no máximo o conceito 5. No caso da Química, a avaliação referente a esse período revelou a existência de um programa 7 , oito programas 6 , nove programas 5 , onze programas 4 e oito programas 3. Esses trinta e sete programas estão disseminados por todo o país, contemplando todas as cinco regiões geográficas, dezesseis estados da Federação e o Distrito Federal.

Como se pode constatar pelos dados da Tabela 1, o crescimento da pós-graduação na área continua sendo intenso. Em comparação com o biênio anterior, o número de dissertações cresceu em quase $50 \%$ e o de teses, em mais de $1 / 3$. A duração média do mestrado 
continua a cair, mas a do doutorado parece ter se estabilizado em torno de cinco anos. O total de alunos matriculados registrou também um aumento de $50 \%$. O crescimento do número de publicações em periódicos indexados nacionais foi modesto, cerca de $25 \%$, mas o número de publicações internacionais quase dobrou, sendo que a relação entre publicações internacionais e publicações nacionais passou a ser de quase $5 / 1$.

Em junho de 1997, a CAPES organizou em Brasília uma reunião de consultores internacionais, com o propósito de realizar uma avaliação de seu programa de avaliação da pós-graduação brasileira, prestes a completar 20 anos. Esse grupo de trabalho de alto nível, constituído por professores de seis diferentes países, apresentou um relatório de trabalho com diversas recomendações. Entre elas, encontra-se uma que nos interessa destacar: a importância de se implementar procedimentos para acompanhar as carreiras dos doutores formados em programas com financiamento da CAPES. De fato, a preocupação em acompanhar o processo de inserção profissional de graduados e pósgraduados, relacionando-o com sua formação, não é uma prática habitual em nosso país. No caso da área de Química, uma procura relativamente exaustiva no periódico Química Nova não revelou, em mais de 20 anos, sequer um trabalho com essa característica.

O propósito da presente pesquisa foi justamente o de começar a preencher essa lacuna, investigando questões relativas à formação e ao trabalho de mestres e doutores em Química titulados nos anos 90, em alguns dos mais antigos cursos de pós-graduação dessa área ${ }^{13}$. Desejava-se conhecer diversos aspectos relativos a esses profissionais, com a intenção de subsidiar a discussão sobre as políticas de pós-graduação para a área no país, além de fornecer elementos para que os programas possam eventualmente redirecionar sua atuação. Quem são os mestres e doutores em Química? Quais as motivações que os levaram a procurar a pós-graduação? Como a titulação alterou a sua trajetória profissional? Qual é hoje a sua inserção no mercado de trabalho, quanto ganham e quão satisfeitos estão? Qual a contribuição do curso para a sua atuação profissional? A resposta a essas questões é matizada por fatores regionais? Responder e refletir sobre essas indagações motivaram a elaboração do projeto pesquisa que resultou no trabalho aqui apresentado.

\section{METODOLOGIA}

O projeto de pesquisa, realizado sob o patrocínio financeiro da CAPES e da UNESCO, incluiu diversas outras áreas do conhecimento, além da Química, resultando em livro recentemente edita$\mathrm{do}^{14}$. O texto aqui apresentado é uma adaptação do capítulo referente à área de Química deste livro, adequando-o às normas da revista e fazendo inclusões que permitam ao leitor a sua ampla compreensão, fora do contexto do livro.

A escolha dos programas a serem pesquisados decorreu de diversos fatores. O primeiro passo foi montar uma rede de pesquisadores convenientemente disseminada por todo o país. O apoio da CAPES permitiu que se realizassem reuniões de grupos interessados situados em Belo Horizonte, Brasília, Campos, Porto Alegre, Rio de Janeiro, São Paulo e Salvador. Posteriormente, na segunda etapa da pesquisa, quando os dados da área de Química já haviam sido colhidos, foram também agregados pesquisadores de Recife.

Um projeto com o escopo proposto envolve custos relativamente elevados, o que recomendava a construção de uma proposta em formato capaz de torná-la compatível com as possibilidades de financiamento. Mister se fez, portanto, eleger programas situados nas mesmas localidades dos grupos de pesquisadores, ou pelo menos próximos delas. Além disto, como a escolha do período a ser pesquisado recaiu sobre os anos de 1990 a 1997 - período mais recente, o que aumenta as chances de localizar o titulado, e que engloba profissionais atuando no mercado há alguns anos - era indispensável que os programas escolhidos tivessem formado estudantes desde 1990. Finalmente, quando em uma mesma região havia mais de um programa que atendia a ambas às características mencionadas, optou-se por aquele de maior tradição, tendo em vista a impossibilidade financeira de incorporar mais de um programa em uma mesma região do país.

Considerando o exposto, foram escolhidos, na área de Química, os programas de pós-graduação das seguintes universidades: UFBA, UnB, UFMG, UFRJ, USP e UFRGS. No caso do doutorado, foram excluídos da análise os dados referentes à UFBA, UnB e UFRGS, uma vez que o número de titulados no período foi inferior a dez, em cada um deles.

O universo a ser pesquisado constituía-se de 460 doutores e 684 mestres.Tais números excluem os mestres que, no mesmo período e nas mesmas instituições a que se referem a pesquisa, concluíram também o doutorado. Estes foram considerados apenas uma vez, como doutores, mesmo que, por exemplo, tenham concluído o mestrado na UnB e o doutorado na USP. As informações iniciais necessárias ao projeto foram obtidas nas secretarias dos programas selecionados. As entrevistas foram realizadas por telefone, utilizando-se um questionário padrão, elaborado em conjunto pelo grupo de pesquisadores, com discussões habituais, pela Internet, e eventuais, em reuniões. Entrevistou-se 53\% do universo dos mestres e 67\%, dos doutores. A sistematização e o processamento dos dados foram realizados pela coordenação do projeto em Brasília ${ }^{15}$, a qual remeteu os bancos de dados construídos ${ }^{16}$ para a análise dos diversos grupos. A análise dos dados foi discutida, também pela Internet, e em um seminário, ocorrido em junho de 2001, no Rio de Janeiro, possível de ser realizado graças, mais uma vez, ao apoio da CAPES.

\section{QUEM SÃO OS MESTRES E DOUTORES EM QUÍMICA}

Para melhor compreender as questões relativas à formação e ao trabalho de mestres e doutores em Química, convém considerar algumas características relevantes dos titulados, relativas à sua formação anterior, sexo, tempo até o ingresso na pós-graduação, duração do curso e idade de titulação, de forma a traçar um perfil dos entrevistados nessa pesquisa.

\section{Origem acadêmica e sexo}

Os mestres em Química ${ }^{17}$ são em sua maior parte mulheres e oriundos de cursos de graduação na mesma área do conhecimento, como se pode observar na Tabela 2. Em relação a esses aspectos, no entanto, há diferenças dignas de menção, entre as instituições formadoras. $\mathrm{Na}$ UFBA e na USP, a proporção de mestres que se graduou também em Química alcança a faixa de $90 \%$; na UFRJ, a maioria dos titulados vêm de outros cursos de graduação. $\mathrm{Na} \mathrm{UnB}$, a proporção de mulheres supera 70\%; na USP, na UFBA e na UFRJ, não alcança 60\%. Entre os doutores $^{18}$, observa-se quadro semelhante, no que concerne à área da graduação: predominância de titulados também graduados em Química, o que é mais pronunciado na USP; em contrapartida, na UFRJ, os doutores em Química graduaram-se preferencialmente em outra área ${ }^{19}$. Cabe mencionar que o percentual de aproximadamente $70 \%$ para a superposição de área entre a pós-graduação e a graduação é um pouco menor do que o observado por Velloso e Velho (mestrado, $77 \%$ e doutorado, 80\%), para a área de Ciências Exatas no Brasil ${ }^{20}$. Quanto à composição de sexo, ela é rigorosamente equilibrada para os doutores, sendo também a USP a universidade que mais forma doutores em Química do sexo masculino.

A menor proporção de mulheres no doutorado, quando comparada ao mestrado, pode sinalizar para o fato de estar em curso um processo de mudança. Uma área que, há alguns anos, teria sido tipicamente mascu- 
Tabela 2. Área da graduação e da pós-graduação; sexo; percentuais por universidade

\begin{tabular}{|c|c|c|c|c|c|c|c|c|}
\hline & & \multicolumn{7}{|c|}{ Universidade do curso } \\
\hline \multicolumn{9}{|l|}{ a. Mestres } \\
\hline \multirow{2}{*}{$\begin{array}{l}\text { Área na graduação } \\
\text { e na pós }\end{array}$} & Outra área & 13,5 & 33,3 & 25,0 & 58,8 & 21,9 & 7,9 & 30,6 \\
\hline & Total & 100,0 & 100,0 & 100,0 & 100,0 & 100,0 & 100,0 & 100,0 \\
\hline Sexo & Total & 100,0 & 100,0 & 100,0 & 100,0 & 100,0 & 100,0 & 100,0 \\
\hline \multicolumn{9}{|l|}{ b. Doutores } \\
\hline \multirow{2}{*}{$\begin{array}{l}\text { Área na graduação } \\
\text { e na pós }\end{array}$} & Mesma área & & 57,4 & & 40,7 & & 82,1 & 68,9 \\
\hline & Outra área & & 42,6 & & 59,3 & & 17,9 & 31,1 \\
\hline Sexo & Total & & 100,0 & & 100,0 & & 100,0 & 100,0 \\
\hline
\end{tabular}

lina, estaria se transformando em uma área feminina e esta "onda" ainda não teria chegado ao doutorado com tanta força. Esse perfil preferencialmente feminino da área já havia sido observado em relação ao curso de graduação em Química da UFMG ${ }^{21}$. Quando se confrontam os dados ora obtidos com aqueles registrados por Velloso ${ }^{20}$ para a grande área de Ciências Exatas no país, observa-se que, na Química, a proporção de mulheres que concluem o mestrado (60\%) é expressivamente maior do que a média da grande área de Exatas (45\%). Em relação ao doutorado, o comportamento observado na Química ainda reproduz a média verificada para a grande área.

Idade de conclusão da graduação, de ingresso na pósgraduação e tempo entre a conclusão da graduação e o ingresso na pós-graduação

As idades médias de graduação e de início e de conclusão da pós-graduação, por ano de titulação, são apresentadas nas Figuras 1a e 1b. Os mestres concluíram a graduação com idade média de

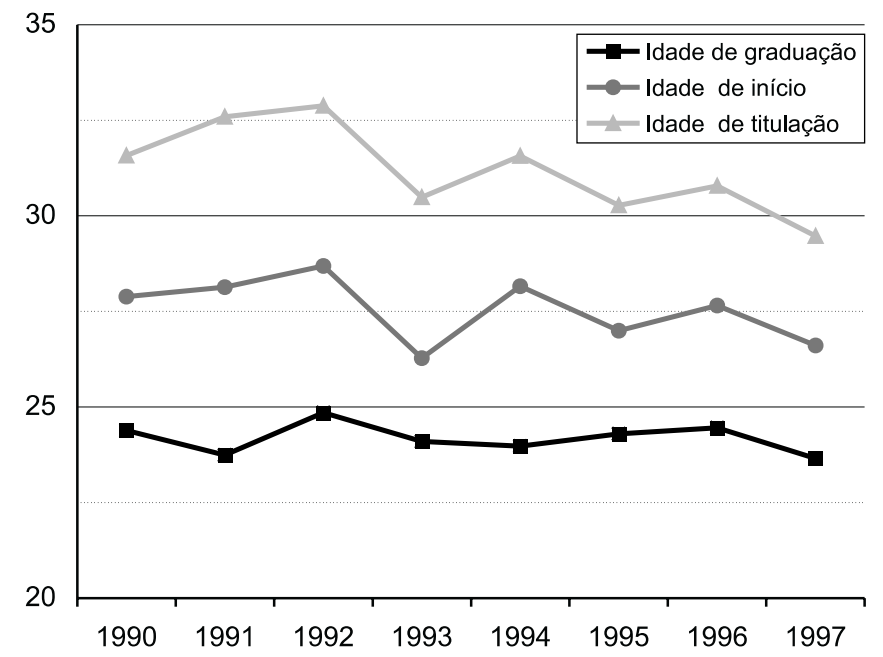

Figura 1a. Idades dos mestres na trajetória da graduação à titulação; médias anuais em anos
$24,1 \operatorname{anos}^{22}$, enquanto que os doutores, com 23,7 anos ${ }^{23}$. Como os doutores geralmente concluíram a graduação há mais tempo do que os mestres, observa-se aqui um indício de que a idade de conclusão da graduação estaria aumentando. Essa regularidade torna-se mais evidente quando se acompanham os doutores, por ano de titulação. Há uma nítida tendência de crescimento dessa idade ao longo da década, como mostrado na Figura 1b. Aqueles que se doutoraram em 90, graduaram-se em média com 23,2 anos, enquanto que os titulados em 97 o fizeram com 24,4 anos. A mesma tendência, entretanto, não é verificada para os mestres. Neste caso, a idade média de conclusão da graduação varia irregularmente com o ano de titulação, o que talvez informe que a tendência de aumento da idade de conclusão da graduação foi interrompida, embora não revertida.

$\mathrm{O}$ interregno entre a graduação e o início da pós-graduação registrou, em todo o período pesquisado, médias de $3,3 \operatorname{anos}^{24}$, para o mestrado, e de 6,6 anos $^{25}$, para o doutorado. A evolução dessa variável, conforme o ano de titulação, apresenta tendências opostas, no mestrado e no doutorado, como pode ser observado na Figura 2. No

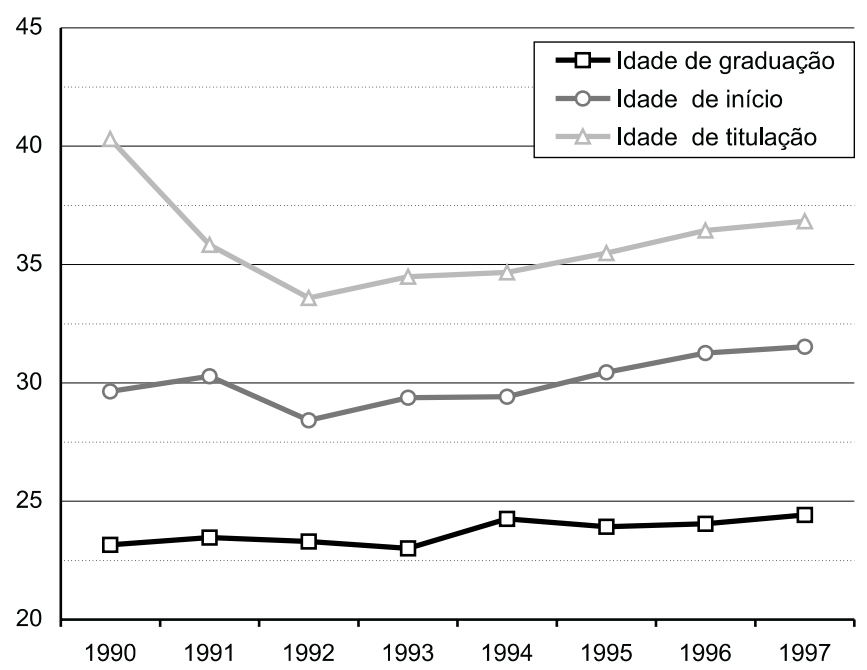

Figura 1b. Idades dos doutores na trajetória da graduação à titulação; médias anuais em anos 
primeiro caso, o ingresso na pós-graduação tende a se aproximar do momento da graduação. O tempo médio correspondente chegou superar a 4 anos, no início da década, e, ao seu final, foi inferior a 3 anos. Essa tendência se caracterizou em razão das médias observadas para as coortes referentes à primeira metade do período estudado, uma vez que a partir de 1995 não se observaram variações expressivas nessa variável. Já no caso do doutorado, observou-se um aumento do tempo médio entre a graduação e o ingresso na pós: para a coorte de 1990, essa média não alcançou a 6,5 anos, enquanto que para a coorte de 1997, é da ordem de 7,5 anos. Nesse caso, também ao contrário do observado para o mestrado, a tendência se caracteriza no período final estudado, ou seja, a partir de 1994.

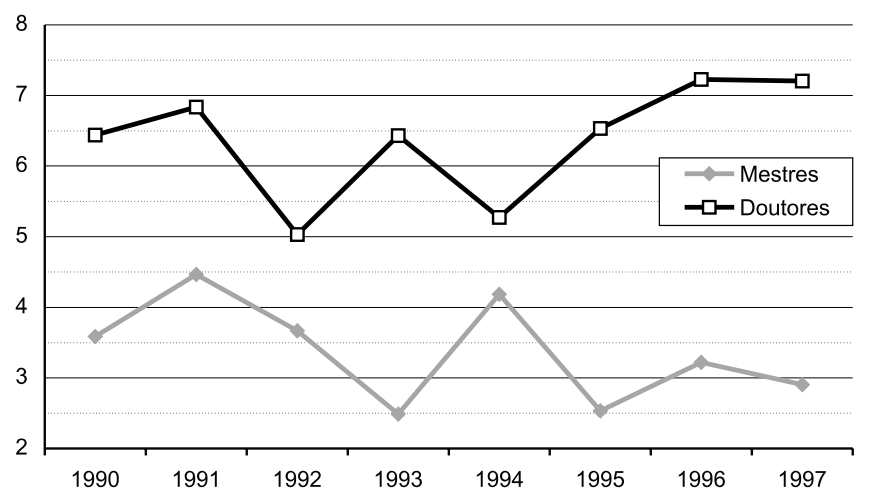

Figura 2. Tempo, em anos, entre a graduação e o início do curso

Às médias de 3,3 anos e de 6,6 anos, para o tempo entre a conclusão da graduação e o início da pós, associam-se elevadas dispersões, caracterizando trajetórias diferentes de grupos expressivos de estudantes, tanto no mestrado quanto no doutorado. Cerca de $2 / 3$ dos mestres ingressaram na pós-graduação até dois anos ${ }^{26}$ depois de concluírem a graduação ${ }^{27}$. Por outro lado, $20 \%$ dos mestres ingressaram na pós em um tempo que varia de 6 até 25 anos após a conclusão da graduação. Entre os que foram admitidos no mestrado até dois anos após se graduarem, apenas 1/4 declarou que, no momento da inscrição, tinha vínculo empregatício; no caso dos que iniciaram o mestrado mais de 5 anos após a graduação, a fração correspondente é cerca de 3/4. Ou seja, aqueles que procuram o mestrado logo em seguida à graduação provavelmente o fazem em decorrência de uma nítida opção pela carreira acadêmica, como professor e pesquisador. Aqueles que se dirigem para o mestrado muito tempo depois de se graduarem provavelmente o fazem em decorrência de novas exigências relacionadas à sua atividade profissional.

No caso dos doutores, a trajetória acadêmica parece ser mais definida e as diferenças observadas devem-se principalmente ao fato de o titulado ter ou não concluído o mestrado anteriormente. Cerca de 3/4 dos doutores titularam-se anteriormente como mestres e gastaram, em média, quase sete anos e meio para chegarem ao doutorado. Tendo em vista que o interregno médio entre a graduação e o início do mestrado é de 3,3 anos e que um tempo igual a este é gasto para a conclusão do mestrado, como será discutido mais adiante, conclui-se que esse grupo tende a procurar o doutorado logo após defender sua dissertação. O tempo médio entre a conclusão do mestrado e o ingresso no doutorado é de 2,1 anos, mas a maior parte é admitida ao doutorado antes disso ${ }^{28}$. Já para aqueles que foram diretamente da graduação para o doutorado, o tempo médio entre o término da graduação e o início do doutorado é de aproximadamente quatro anos e meio. Considerando que muitos deles, talvez a maioria, foram admitidos ao mestrado, para posteriormente pleitearem a passagem para o doutorado, a grande maioria desse segundo grupo foi admitida à pós-graduação logo em seguida ao término da graduação ${ }^{29}$. Trata-se portanto, muito provavelmente, de jovens estudantes de desempenho acadêmico destacado. Há, entretanto, nesse segundo grupo, um percentual de entrevistados, correspondendo a $25 \%$ deles e a $5 \%$ do universo dos doutores, que foram admitidos no doutorado muitos anos - entre sete e dezenove - após se graduarem. Nesses casos, talvez, o ingresso direto ao doutorado tenha sido decorrente da experiência profissional prévia do candidato e de seu interesse específico pelo doutorado e não pelo mestrado ${ }^{30}$.

A idade média de início da pós-graduação é de 27 anos para o mestrado, e de 30 anos para o doutorado. A evolução dessas médias com o tempo também apresenta comportamento diferente em um e em outro caso, como pode ser observado nas Figuras 1a e 1b. No mestrado, verifica-se uma pequena tendência de diminuição da idade de ingresso, conseqüência certamente da diminuição do interregno entre a graduação e o início do mestrado. Quando se comparam as coortes de 1990 a 1994, no seu conjunto, com as coortes de 1995 a 1998, também tomadas no seu todo ${ }^{31}$, essa diminuição alcança a 0,8 anos. Já no doutorado, há um sensível acréscimo na idade de ingresso, que chega a cerca de dois anos, quando se comparam os mesmos conjuntos de coortes. Esse fato decorre de dois fatores: o aumento da idade média de graduação e o aumento do interregno entre o término da graduação e o início do doutorado, ambos abordados anteriormente. $\mathrm{O}$ primeiro deles tem peso bem menor do que o segundo.

\section{Duração do curso e idade de titulação}

A duração média do mestrado é de 3,3 anos ${ }^{32}$ e a doutorado, de 5,1 $\operatorname{anos}^{33}$. No primeiro caso, há um pronunciado decréscimo dessa média ao longo do período estudado, variando de 4 anos em 1990, para menos de 3 anos, em 1997, conforme ilustra a Figura 3. Provavelmente este fato é uma consequiência direta de políticas que vêm sendo adotadas pelas agências de fomento, especialmente a CAPES, voltadas para a melhoria da produtividade dos cursos de pós-graduação stricto sensu, o que inclui a diminuição do prazo para titulação. Já no caso do doutorado, a duração do curso, que é um pouco maior, 5,4 anos, para aqueles que foram diretamente da graduação para o doutorado, manteve-se praticamente estável ao longo do tempo estudado (ver Figura 3), sugerindo que esse tempo alcançou um valor médio compatível com a regulamentação da pós-graduação e com as condições dos laboratórios de pesquisa das instituições estudadas ${ }^{34}$.

Há, entretanto, abordagens diferenciadas em relação a esse aspecto, para além das simples comparações dos tempos médios por coortes, que parecem indicar uma tendência de diminuição na duração do curso, também para o doutorado. Ocorre que os valores médios antes mencionados incluem os dados referentes a estudantes

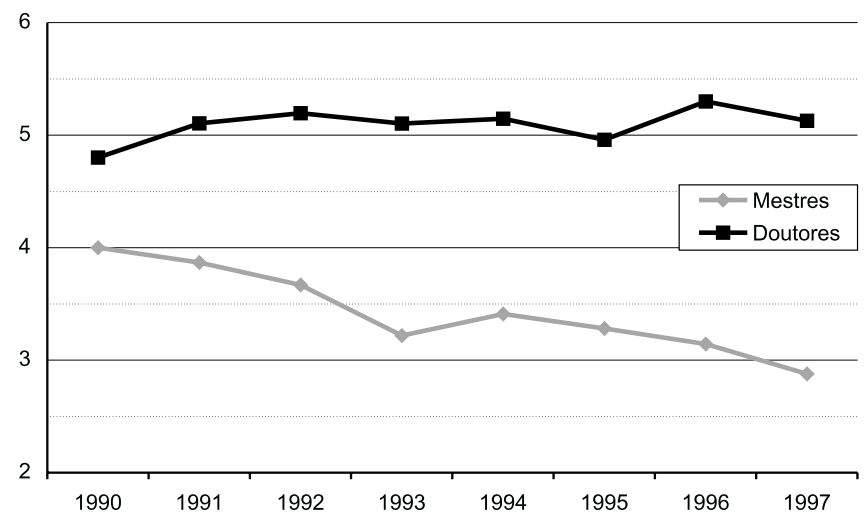

Figura 3. Duração do curso em anos, médias por ano de conclusão 
que ingressaram na pós-graduação no início dos anos 80 e que levaram muitos anos para defender a sua tese. Em contrapartida, aqueles de sua geração que foram mais eficientes não integram a pesquisa atual, porque titularam-se anteriormente a 1990. Uma alternativa para superar essa dificuldade é considerar apenas os entrevistados que ingressaram no doutorado e que se titularam no período considerado pela pesquisa ${ }^{35}$. Quando isso é feito, verifica-se uma nítida tendência de diminuição da duração do doutorado. É preciso reconhecer que esse raciocínio peca por deixar de considerar aqueles estudantes que ingressaram no doutorado na década de 90 e que ainda não se titularam. Entretanto, diante das políticas dos órgãos de fomento e dos critérios de avaliação da pós-graduação, parece difícil que se repitam, para os estudantes que ingressaram no doutorado a partir de 1990, casos de duração de curso de 7 ou mais anos, que representam quase $10 \%$ do universo de doutores entrevistados. Se assim o for, o raciocínio continua válido e deve-se esperar que, nos próximos anos, a duração média do doutorado, nos programas pesquisados, venha a registrar valor menor do que o apontado neste trabalho.

A duração do curso, tanto no mestrado como no doutorado, é significativamente maior para aqueles que trabalhavam quando se inscreveram para a pós-graduação (mestrado, 3,7 anos; doutorado, 5,4 anos), quando comparados aos que não trabalhavam naquela ocasião (mestrado, 2,9 anos; doutorado, 4,8 anos). Tal fato pode sugerir que a relação de trabalho anterior ao ingresso no curso foi, ao menos parcialmente, mantida após a admissão. Poder-se-ia também imaginar que aqueles que se afastaram dos bancos escolares por um certo tempo tiveram maiores dificuldades para se readaptar à vida estudantil. Essa hipótese, entretanto, parece menos provável, ou contribuiria menos para esse fato, uma vez que não se observam diferenças expressivas na duração do curso entre aqueles que ingressaram na pós-graduação logo após concluírem a graduação e os que o fizeram em maior tempo.

A duração do doutorado é cerca de $10 \%$ maior para aqueles que cursaram a graduação também em Química, fato à primeira vista inesperado. Essa mesma regularidade é observada em relação aos mestres $^{36}$. Embora relativamente pequena, esta diferença é verificada em todas as universidades ${ }^{37}$, exceto na UnB. Uma possível explicação para este fato é a que se segue. No caso da Química, embora os dados da presente pesquisa não permitam a confirmação dessa assertiva, é sabido que os graduados em outras áreas que procuram a pós-graduação são geralmente oriundos de cursos de Farmácia ou de
Engenharia Química. Em trabalho recente, referente aos candidatos aos cursos de graduação da UFMG na década de $90^{38}$, verificou-se que estes estudantes têm um perfil sócio-econômico típico de classe média ou classe média alta, enquanto que no caso dos estudantes de Química, esse perfil é de classe média baixa ou de estratos sociais ainda inferiores. É possível supor que o percurso da graduação, e até mesmo do mestrado, não tenha sido suficiente para eliminar completamente as diferenças de potencialidades advindas da origem do estudante, fato que acabaria se refletindo na duração dos cursos.

A Tabela 3 apresenta os mestres e doutores em Química por faixa etária de titulação, conforme a instituição formadora. Quase $60 \%$ dos mestres se titulam até os 30 anos, mas o que chama mais a atenção é o elevado percentual dos que se titulam acima dessa idade. $\mathrm{Na}$ UFMG, a fração dos que se titulam mais jovens é significativamente maior do que a média e, na UFBA, bem menor. Entre os doutores, não chega a $1 / 5$ a fração dos que concluem o curso com até 30 anos e a maior parte o faz entre 31 e 35 anos. Ao contrário do observado para o mestrado, na UFMG encontra-se a menor proporção dos que se titulam mais jovens. Em contrapartida, na UFRJ a fração dos que se titulam na faixa mais jovem é superior a $1 / 4$.

A idade média de titulação é de 31 anos, para o mestrado e de 36 anos, para o doutorado. Esses valores são extremamente elevados, quando comparados a padrões internacionais, que situam o doutoramento, na área de Química ou em áreas próximas, tanto nos EUA, como em países da Europa ocidental, na faixa dos 28 $\operatorname{anos}^{20,39}$. Novamente observam-se tendências divergentes para o mestrado e o doutorado, conforme pode ser verificado nas Figuras 1a e 1b. No caso dos mestres, a idade de titulação diminuiu em cerca de dois anos no período considerado. Essa tendência decorre de dois fatores já discutidos: a procura mais precoce pelo mestrado e a menor duração do curso, para as coortes mais recentes. Para os doutores, o que se observa, a partir de 1993, é o aumento expressivo e paulatino da idade de titulação, aumento esse que é superior a 3 anos, quando se comparam as coortes de 1992 e 1997. A idade média de doutoramento é significativamente menor para aqueles que vão direto da graduação para o doutorado. Para estes últimos, o valor encontrado é de 33,9 anos, em contraste com os 36,5 anos de seus colegas que passaram pela etapa do mestrado.

As informações colhidas nesta pesquisa permitem ainda estimar a idade média de doutoramento para os próximos anos. Isso pode ser

Tabela 3. Idade de titulação em grupos etários por universidade; percentuais

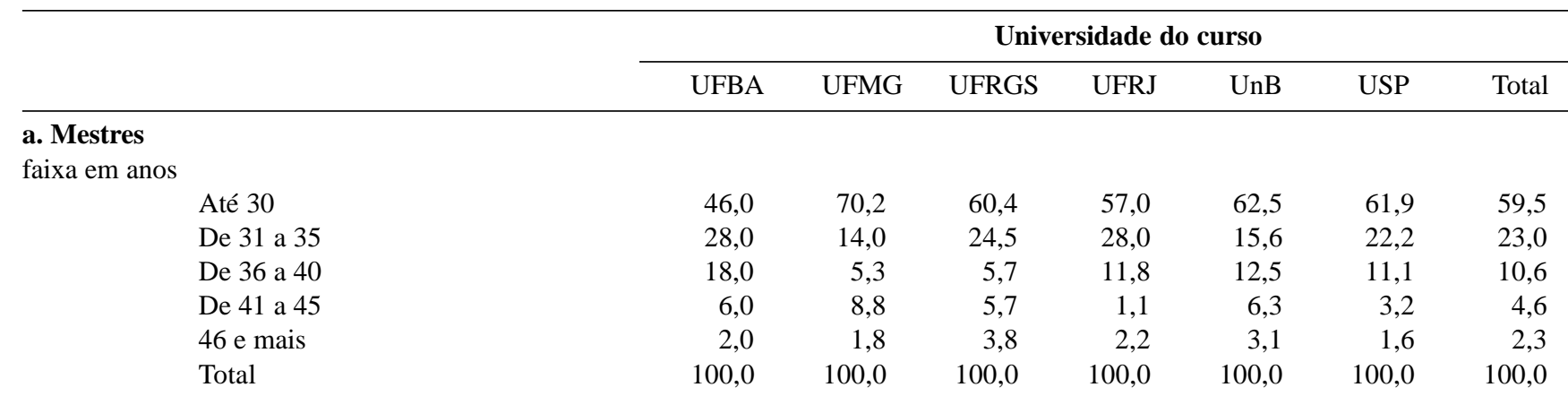

\section{b. Doutores}

faixa em anos
Até 30
De 31 a 35
De 36 a 40
De 41 a 45
46 e mais
Total

$\begin{array}{rr}11,5 & 26,8 \\ 39,3 & 30,5 \\ 27,9 & 25,6 \\ 14,8 & 15,9 \\ 6,6 & 1,2 \\ 100,0 & 100,0\end{array}$

$\begin{array}{rr}18,0 & 19,0 \\ 37,1 & 35,8 \\ 23,4 & 24,8 \\ 12,6 & 13,9 \\ 9,0 & 6,5 \\ 100,0 & 100,0\end{array}$


feito considerando-se a idade média de titulação no mestrado, o tempo médio decorrido entre a conclusão do mestrado e o início do doutorado e a duração do doutorado. A soma dessas parcelas corresponderia à idade média daqueles que passam pelo mestrado antes de chegar ao doutorado, que representam 75\% dos doutores em Química. Para os outros $25 \%$, aqueles que vão direto da graduação para o doutorado, supõe-se que a idade média de titulação continuará a ser a mesma observada nesta pesquisa ${ }^{40}$. Quando esse exercício é feito, encontra-se uma idade média variando entre 36,2 e 37,2 anos, conforme sejam considerados todos os mestres ou apenas aqueles que já se encontram vinculados a programas de doutorado. Ou seja, na melhor das hipóteses o que se pode prever é que a idade média de doutoramento permanecerá superior a 36 anos, com uma defasagem de cerca de 8 anos em relação aos padrões internacionais.

Quais as razões para o aumento da idade média de doutoramento e da perspectiva de que esse quadro não será revertido nos próximos anos? Para tentar responder a essa questão serão comparados os dados relativos às coortes de 1990 a 1994, com aqueles referentes às coortes de 1995 a 1997. Quando isso é feito, verifica-se que todos os tempos médios referentes à trajetória acadêmica dos doutores aumentaram: a idade de graduação, o tempo entre a graduação e o início do doutorado e, até mesmo, o tempo entre a conclusão do mestrado e o início do doutorado, para os que passaram pela etapa do mestrado antes de se dirigirem para o doutorado. Isso certamente explica por que a idade média de doutoramento aumentou ao longo das coortes estudadas. Mas, por que essa tendência não será alterada nos próximos anos, se, para os mestres, a idade de graduação não está aumentando, a procura pelo mestrado está se fazendo mais rapidamente e a duração do curso está diminuindo? Ocorre que, a despeito disso tudo, quando se compara o universo de mestres com o de doutores, os últimos ainda apresentam indicadores mais favoráveis, em relação a esses aspectos. Por exemplo, a idade média de graduação dos mestres, embora não esteja aumentando, ainda é maior do que a dos doutores. O mesmo vale para a idade de conclusão do mestrado: para os mestres ela é de 31 anos, para os doutores que anteriormente concluíram o mestrado, ela foi de 29 anos.

Os resultados colhidos nessa pesquisa indicam a conveniência de serem adotadas políticas com o propósito de diminuir a idade de titulação dos doutores em Química. O que foi apresentado sugere também que uma das alternativas para se alcançar esse objetivo seria estimular a trajetória direta da graduação para o doutorado, eliminando-se a etapa do mestrado. Como visto, os doutores que assim procedem concluem seus cursos quase 3 anos mais jovens do que seus colegas. Há ainda que se considerar que a maior parte dos mestres dirige-se para o doutorado logo em seguida à defesa da dissertação (quase dois terços dos mestres titulados nas coortes de 96 e 97 já se encontravam, no momento da entrevista, vinculados a programas de doutorado). Dadas as características da área, é razoável supor que a opção pelo doutorado já havia sido tomada no momento do ingresso no mestrado. Ademais, ao se estimular a trajetória direta da graduação para o mestrado, talvez se estimule também o remodelamento do mestrado na área, dando-lhe características de um programa destinado ao atendimento de uma demanda profissional e atraindo para a pós-graduação em Química também aquele estudante que não optou por uma carreira na área acadêmica.

\section{ESTUDO E TRABALHO DE MESTRES E DOUTORES QUANDO SE INSCREVERAM NA PÓS-GRADUAÇÃO}

A parcela dos mestres e dos doutores com atividade profissional plena ao se inscrever na pós-graduação é semelhante: cerca de $40 \%$ em ambos os casos, como apresentado nas Tabelas 4a e 4b. Obser-

Tabela 4a. Situação de trabalho dos mestres na inscrição por universidade; percentuais

\begin{tabular}{|c|c|c|c|c|c|c|c|c|}
\hline & & \multicolumn{7}{|c|}{ Universidade do curso } \\
\hline & & UFBA & UFMG & UFRGS & UFRJ & UnB & USP & Total \\
\hline \multirow{5}{*}{$\begin{array}{l}\text { Trabalho } \\
\text { na inscrição }\end{array}$} & Procurava trabalho & & & & 8,0 & 22,9 & 3,2 & 5,0 \\
\hline & Outra & 44,2 & 66,7 & 73,1 & 51,0 & 20,0 & 43,5 & 51,4 \\
\hline & Plena atividade & 55,8 & 31,6 & 25,0 & 37,0 & 57,1 & 51,6 & 41,6 \\
\hline & Parc./tot. afastado & & 1,8 & 1,9 & 4,0 & & 1,6 & 2,0 \\
\hline & Total & 100,0 & 100,0 & 100,0 & 100,0 & 100,0 & 100,0 & 100,0 \\
\hline \multirow{4}{*}{$\begin{array}{l}\text { Atividade } \\
\text { remunerada } \\
\text { na inscrição }\end{array}$} & Emp. setor público & 51,7 & 57,9 & 21,4 & 61,0 & 65,0 & 45,5 & 52,6 \\
\hline & Emp. setor privado & 48,3 & 42,1 & 78,6 & 36,6 & 30,0 & 54,5 & 46,2 \\
\hline & ONG/entidades & & & & 2,4 & 5,0 & & 1,3 \\
\hline & Total & 100,0 & 100,0 & 100,0 & 100,0 & 100,0 & 100,0 & 100,0 \\
\hline \multirow{7}{*}{$\begin{array}{l}\text { Tipo de trabalho } \\
\text { na inscrição }\end{array}$} & Administração públ. & 20,7 & & & 7,3 & 50,0 & & 12,2 \\
\hline & Empresa & 34,5 & 21,1 & 35,7 & 36,6 & & 39,4 & 30,1 \\
\hline & IES & 24,1 & 26,3 & 50,0 & 17,1 & 30,0 & 21,2 & 25,0 \\
\hline & Outra instit. de ensino & 17,2 & 36,8 & 14,3 & 12,2 & 20,0 & 9,1 & 16,7 \\
\hline & Instituição pesquisa & 3,4 & 15,8 & & 24,4 & & 30,3 & 15,4 \\
\hline & Inst. assessoria & & & & 2,4 & & & 0,6 \\
\hline & Total & 100,0 & 100,0 & 100,0 & 100,0 & 100,0 & 100,0 & 100,0 \\
\hline \multirow{3}{*}{$\begin{array}{l}\text { Atividade } \\
\text { envolvia } \\
\text { pesquisa }\end{array}$} & Não & 44,8 & 73,7 & 50,0 & 31,7 & 75,0 & 48,5 & 50,0 \\
\hline & Sim & 55,2 & 26,3 & 50,0 & 68,3 & 25,0 & 51,5 & 50,0 \\
\hline & Total & 100,0 & 100,0 & 100,0 & 100,0 & 100,0 & 100,0 & 100,0 \\
\hline \multirow{3}{*}{$\begin{array}{l}\text { Era docente em } \\
\text { universidade }\end{array}$} & Não & 75,9 & 73,7 & 58,3 & 92,7 & 65,0 & 84,8 & 79,2 \\
\hline & Sim & 24,1 & 26,3 & 41,7 & 7,3 & 35,0 & 15,2 & 20,8 \\
\hline & Total & 100,0 & 100,0 & 100,0 & 100,0 & 100,0 & 100,0 & 100,0 \\
\hline
\end{tabular}


Tabela 4b. Situação de trabalho dos doutores na inscrição por universidade; percentuais

\begin{tabular}{|c|c|c|c|c|c|}
\hline & & \multicolumn{4}{|c|}{ Universidade do curso } \\
\hline & & UFMG & UFRJ & USP & Total \\
\hline \multirow{4}{*}{$\begin{array}{l}\text { Trabalho } \\
\text { na inscrição }\end{array}$} & Procurava trabalho & 1,7 & 2,4 & 1,2 & 1,6 \\
\hline & Plena atividade & 50,0 & 35,4 & 44,6 & 43,2 \\
\hline & Parc./tot. afastado & 5,0 & 6,1 & 11,3 & 8,7 \\
\hline & Total & 100,0 & 100,0 & 100,0 & 100,0 \\
\hline \multirow{3}{*}{$\begin{array}{l}\text { Atividade } \\
\text { remunerada } \\
\text { na inscrição }\end{array}$} & Emp. setor priv. & 11,8 & 17,6 & 25,8 & 21,1 \\
\hline & Autônomo/consultor & & & 1,1 & 0,6 \\
\hline & Total & 100,0 & 100,0 & 100,0 & 100,0 \\
\hline \multirow{3}{*}{$\begin{array}{l}\text { Tipo de trabalho } \\
\text { na inscrição }\end{array}$} & Administração pública & & 3,0 & 4,3 & 3,1 \\
\hline & Outras & & & 1,1 & 0,6 \\
\hline & Total & 100,0 & 100,0 & 100,0 & 100,0 \\
\hline \multirow{3}{*}{$\begin{array}{l}\text { Atividade } \\
\text { envolvia } \\
\text { pesquisa }\end{array}$} & Não & 33,3 & 8,8 & 29,8 & 26,1 \\
\hline & Sim & 66,7 & 91,2 & 70,2 & 73,9 \\
\hline & Total & 100,0 & 100,0 & 100,0 & 100,0 \\
\hline \multirow{3}{*}{$\begin{array}{l}\text { Era docente em } \\
\text { universidade }\end{array}$} & Não & 24,2 & 61,8 & 42,6 & 42,9 \\
\hline & Sim & 75,8 & 38,2 & 57,4 & 57,1 \\
\hline & Total & 100,0 & 100,0 & 100,0 & 100,0 \\
\hline
\end{tabular}

vam-se, no entanto, diferenças significativas neste quesito, quando cada instituição formadora é considerada. Entre os mestres, há um grupo de instituições, UFBA, UnB e USP, cuja proporção dos que tinham atividade profissional plena supera $50 \%$, enquanto que nas outras três universidades essa percentagem é bem menor. No caso dos doutores, as diferenças são um pouco menores, mas ainda assim expressivas, quando se compara a UFMG com a UFRJ.

A maior parte de mestres e doutores declarou se encontrar em “outra situação de trabalho", quando se inscreveu na pós-graduação. O que se pode depreender da análise dos dados colhidos é que a grande maioria desses ou ainda era estudante - de graduação ou de mestrado - ou tinha concluído recentemente sua formação anterior e aguardava a oportunidade para ingresso na pós-graduação ${ }^{41}$.

Conquanto a fração de mestres e doutores que desenvolviam atividade profissional plena ao se inscreverem na pós-graduação seja semelhante, as características desta atividade eram bem distintas, em um e outro caso. No caso dos mestres, a divisão entre setor público e setor privado era quase eqüitativa; $30 \%$ trabalhavam em empresas; apenas $20 \%$ eram docentes do ensino superior e a metade deles declarou que desenvolvia pesquisa em seu trabalho. Já entre os doutores, quase $80 \%$ eram empregados do setor público; pouco mais de $10 \%$ trabalhavam em empresas; quase $60 \%$ eram docentes do ensino superior e cerca de 3/4 declararam que desenvolviam pesquisa em seu trabalho.

Essas características da atividade profissional de mestres e doutores quando da inscrição na pós-graduação tendem a se repetir, no geral, em todas as instituições formadoras, ainda que algumas diferenças devam ser mencionadas. Os mestres titulados pela UFRGS são os que mais se diferenciam de seus colegas. Entre eles predomi- na francamente o emprego no setor privado e a docência no ensino superior ocorre em freqüência duas vezes superior à média global. Já os mestres titulados pela UFMG e pela UnB realizavam pesquisas em proporção bem inferior aos seus colegas de outras universidades. No caso dos doutores, a atuação profissional quando da inscrição na pós era ainda mais homogênea. Talvez a peculiaridade mais expressiva seja a elevada proporção dos titulados pela UFRJ que se vinculava a atividades profissionais envolvendo a realização de pesquisas.

Esse perfil absolutamente distinto da atividade laboral de mestres e doutores, quando da inscrição na pós-graduação, pode ser consequiência do pequeno número de oportunidades de trabalho no setor acadêmico público para profissionais sem formação pós-graduada. Afinal, a grande maioria dos doutores cursou anteriormente o mestrado e cerca de $60 \%$ dos mestres já estão cursando o doutorado.

A fração de mestres e doutores que declarou estar procurando trabalho quando se inscreveu na pós-graduação é bem pequena. Tal característica é observada em todas as instituições, com uma pequena exceção para os mestres da UnB, uma vez que quase $1 / 4$ destes procuravam trabalho. Aparentemente, pode parecer de difícil compreensão o fato de tão poucos estarem procurando trabalho, se mais da metade deles não desenvolvia atividade profissional plena. Ocorre que a maior parte não procurava trabalho porque ainda era estudante. Mais de 3/4 daqueles que não tinham atividade profissional plena à época da inscrição na pós-graduação eram estudantes, tanto no caso dos mestres quanto dos doutores, o que faz supor que ainda estavam na graduação ou no mestrado. Acrescente-se a isso o fato de que mais de $80 \%$ dos mestres e de $90 \%$ dos doutores que a essa época não tinham atividade profissional registraram interregno máximo de um ano entre a conclusão de uma formação e o início da 
outra. Ou seja, aqueles que já não eram mais formalmente estudantes tinham concluído recentemente a graduação ou o mestrado e optaram por, de imediato, prosseguir seus estudos.

\section{MOTIVAÇÕES PARA A PÓS-GRADUAÇÃO SENSO ESTRITO}

A Tabela 5 indica as razões que levaram mestres e doutores a procurarem a pós-graduação. A necessidade de corrigir deficiências da graduação e o incentivo da bolsa tiveram pequena influência nesta opção. Entre os mestres, reparar falhas da graduação ainda teve alguma importância, visto que cerca $1 / 4$ dos entrevistados informou que este fator pesou muito, para a sua motivação. No caso dos doutores, apenas cerca de 5\% atribuíram muita importância a este fator.
No entanto, no caso daqueles que trabalhavam em empresas, esse percentual é três vezes maior.

O incentivo representado pela bolsa parece não ter influenciado na decisão de mais da metade de mestres e doutores. Somente $10 \%$ dos doutores e $16 \%$ dos mestres apontaram este fator como muito importante para a sua escolha. No entanto, convém registrar que muitos dos entrevistados informaram espontaneamente aos estagiários que, embora a bolsa não tenha sido o fator que os levaram à pósgraduação, sem ela, eles não teriam condições de se dedicarem ao mestrado ou ao doutorado.

Tanto mestres como doutores, independentemente do tipo de trabalho que realizavam, ingressaram na pós-graduação influenciados principalmente pela vontade de seguir a carreira de pesquisador. Este fator é apontado como muito importante por mais de $90 \%$ dos dou-

Tabela 5. Motivações para o mestrado e o doutorado por principais tipos de trabalho na inscrição; percentuais

\begin{tabular}{|c|c|c|c|c|c|c|}
\hline & & Empresa & Universidade & $\begin{array}{l}\text { Outra inst. } \\
\text { ensino }\end{array}$ & $\begin{array}{l}\text { Instituição } \\
\text { de pequisa }\end{array}$ & Total $(*)$ \\
\hline \multicolumn{7}{|l|}{ a. Mestres } \\
\hline \multirow{3}{*}{$\begin{array}{l}\text { Corrigir deficiências } \\
\text { da graduação }\end{array}$} & Pouco /nada & 81,1 & 76,5 & 73,9 & 85,7 & 75,8 \\
\hline & Muito & 18,9 & 23,5 & 26,1 & 14,3 & 24,2 \\
\hline & Total & 100,0 & 100,0 & 100,0 & 100,0 & 100,0 \\
\hline \multirow{3}{*}{$\begin{array}{l}\text { Seguir/ aprimorar } \\
\text { carreira docente }\end{array}$} & Pouco /nada & 62,2 & 20,6 & 26,1 & 81,0 & 45,5 \\
\hline & Muito & 37,8 & 79,4 & 73,9 & 19,0 & 54,5 \\
\hline & Total & 100,0 & 100,0 & 100,0 & 100,0 & 100,0 \\
\hline \multirow{3}{*}{$\begin{array}{l}\text { Seguir carreira } \\
\text { de pesquisador }\end{array}$} & Pouco /nada & 13,5 & 32,4 & 30,4 & 14,3 & 23,5 \\
\hline & Muito & 86,5 & 67,6 & 69,6 & 85,7 & 76,5 \\
\hline & Total & 100,0 & 100,0 & 100,0 & 100,0 & 100,0 \\
\hline \multirow{3}{*}{$\begin{array}{l}\text { Melhorar a } \\
\text { competitividade } \\
\text { no mercado }\end{array}$} & Pouco /nada & 35,1 & 51,5 & 26,1 & 38,1 & 38,2 \\
\hline & Muito & 64,9 & 48,5 & 73,9 & 61,9 & 61,8 \\
\hline & Total & 100,0 & 100,0 & 100,0 & 100,0 & 100,0 \\
\hline \multirow{3}{*}{$\begin{array}{l}\text { Incentivo } \\
\text { da bolsa } \\
\text { Total }\end{array}$} & Pouco /nada & 86,5 & 85,3 & 82,6 & 85,7 & 84,1 \\
\hline & Muito & 13,5 & 14,7 & 17,4 & 14,3 & 15,9 \\
\hline & Total & 100,0 & 100,0 & 100,0 & 100,0 & 100,0 \\
\hline \multicolumn{7}{|l|}{ b. Doutores } \\
\hline \multirow{3}{*}{$\begin{array}{l}\text { Corrigir deficiências } \\
\text { da graduação }\end{array}$} & Pouco /nada & & 94,5 & & 95,8 & 94,0 \\
\hline & Muito & & 5,5 & & 4,2 & 6,0 \\
\hline & Total & & 100,0 & & 100,0 & 100,0 \\
\hline \multirow{3}{*}{$\begin{array}{l}\text { Seguir/ aprimorar } \\
\text { carreira docente }\end{array}$} & Pouco /nada & & 11,1 & & 58,3 & 24,7 \\
\hline & Muito & & 88,9 & & 41,7 & 75,3 \\
\hline & Total & & 100,0 & & 100,0 & 100,0 \\
\hline \multirow{3}{*}{$\begin{array}{l}\text { Seguir carreira } \\
\text { de pesquisador }\end{array}$} & Pouco /nada & & 5,5 & & 4,3 & 7,3 \\
\hline & Muito & & 94,5 & & 95,7 & 92,7 \\
\hline & Total & & 100,0 & & 100,0 & 100,0 \\
\hline \multirow{3}{*}{$\begin{array}{l}\text { Melhorar a } \\
\text { competitividade } \\
\text { no mercado }\end{array}$} & Pouco /nada & & 53,8 & & 47,8 & 49,3 \\
\hline & Muito & & 46,2 & & 52,2 & 50,7 \\
\hline & Total & & 100,0 & & 100,0 & 100,0 \\
\hline \multirow{3}{*}{$\begin{array}{l}\text { Incentivo } \\
\text { da bolsa } \\
\text { Total }\end{array}$} & Pouco /nada & & 91,2 & & 79,2 & 90,1 \\
\hline & Muito & & 8,8 & & 20,8 & 9,9 \\
\hline & Total & & 100,0 & & 100,0 & 100,0 \\
\hline
\end{tabular}

Nota (*) - Os dados da col. Total inclui outros tipos de trabalho na época da inscrição (ver Tabelas 4a e 4b) 
tores e por cerca de 3/4 dos mestres. A vontade de seguir ou aprimorar carreira docente vem logo a seguir, citada como muito importante por três quartos dos doutores e por mais da metade dos mestres. Entretanto, para os que trabalhavam em empresas ou em institutos de pesquisa, esse fator foi bem menos importante. Quando se comparam essas duas motivações - "seguir/aprimorar carreira docente" e "seguir carreira de pesquisador" - observa-se que a segunda tem maior impacto do que a primeira, exceto entre aqueles que já eram professores quando se inscreveram na pós-graduação. Isso ocorre a despeito do mercado de trabalho no magistério superior ser o que atrai a maior parte dos pós-graduados em Química, como se verá na próxima seção.

O desejo de melhorar a competitividade no mercado de trabalho também foi um fator identificado pelos entrevistados, sobretudo no caso dos doutores, como importante para a procura pela pós-graduação. Mas talvez surpreenda um pouco o fato de apenas a metade dos doutores e menos de dois terços dos mestres terem considerado ser esta uma motivação muito importante. Como se verá mais adiante, o padrão salarial dos químicos, mestres ou doutores, é modesto, quando comparado ao dos pós-graduados de outras áreas ${ }^{42}$. Certamente, para os apenas graduados ele é menor ainda. Seria portanto natural supor que a pós-graduação fosse buscada também como uma forma de ascensão social. No entanto, isso é verdade apenas para pouco mais da metade dos titulados. É de se questionar se esse tipo de quesito não provocaria constrangimentos em uma parte dos entrevistados, que consideraria pouco nobre associar motivações de cunho material à sua vontade de prosseguir estudos.

\section{ESTUDO E TRABALHO DE MESTRES E DOUTORES APÓS A TITULAÇÃO}

As Tabelas 6a e 6b informam sobre a situação de estudo e trabalho atual de mestres e doutores. Quase $60 \%$ dos mestres já estão cursando o doutorado, situação que ocorre com mais frequiência entre os titulados pela UFMG e, sobretudo, pela USP. Em contrapartida, entre os diplomados pela UnB essa característica é pouco comum. Já no caso dos doutores, cerca de $1 / 3$ prosseguiu os estudos, quase sempre por meio de estágios de pós-doutorado. Ressalte-se que essa prática é mais habitual entre os diplomados pela USP.

Quase dois terços dos mestres e mais de $90 \%$ dos doutores encontram-se em plena atividade profissional. Quando se comparam esses dados com a situação de trabalho anterior à pós-graduação,

Tabela 6a. Situação de estudo e trabalho atual dos mestres por universidade; percentuais

\begin{tabular}{|c|c|c|c|c|c|c|c|c|}
\hline & & \multicolumn{7}{|c|}{ Universidade do curso } \\
\hline & & UFBA & UFMG & UFRGS & UFRJ & UnB & USP & Total \\
\hline \multirow{6}{*}{$\begin{array}{l}\text { Pós-graduação } \\
\text { após o mestrado }\end{array}$} & Faz PG lato sensu & & & 5,7 & 3,0 & 2,9 & & 1,9 \\
\hline & Faz dout. país & 50,0 & 64,9 & 49,1 & 55,0 & 28,6 & 73,0 & 55,6 \\
\hline & Faz dout. sand. ou exter. & & 1,8 & 1,9 & 2,0 & & 1,6 & 1,4 \\
\hline & Faz outra PG & & & & 1,0 & & & 0,3 \\
\hline & Não faz PG & 50,0 & 33,3 & 43,4 & 39,0 & 68,6 & 25,4 & 40,8 \\
\hline & Total & 100,0 & 100,0 & 100,0 & 100,0 & 100,0 & 100,0 & 100,0 \\
\hline \multirow[t]{6}{*}{ Trabalho } & Procura trabalho & & & & 6,0 & & 1,6 & 2,0 \\
\hline & Aposentado & & & 3,9 & 1,0 & 2,9 & & 1,1 \\
\hline & Outra & 26,9 & 47,4 & 31,4 & 26,0 & 14,3 & 23,8 & 28,8 \\
\hline & Plena atividade & 71,2 & 47,4 & 54,9 & 64,0 & 82,9 & 73,0 & 64,5 \\
\hline & Parc./tot. afastado & 1,9 & 5,3 & 9,8 & 3,0 & & 1,6 & 3,6 \\
\hline & Total & 100,0 & 100,0 & 100,0 & 100,0 & 100,0 & 100,0 & 100,0 \\
\hline \multirow{6}{*}{$\begin{array}{l}\text { Atividade } \\
\text { remunerada }\end{array}$} & Emp. setor públ. & 73,7 & 73,3 & 26,5 & 65,7 & 58,6 & 67,4 & 61,9 \\
\hline & Emp. setor priv. & 23,7 & 23,3 & 67,6 & 31,3 & 37,9 & 32,6 & 35,2 \\
\hline & Autônomo/cons. & 2,6 & & 2,9 & 1,5 & & & 1,2 \\
\hline & Proprietário & & & 2,9 & 1,5 & & & 0,8 \\
\hline & ONG/entidades & & 3,3 & & & 3,4 & & 0,8 \\
\hline & Total & 100,0 & 100,0 & 100,0 & 100,0 & 100,0 & 100,0 & 100,0 \\
\hline \multirow[t]{7}{*}{ Tipo de trabalho } & Admin. públ. & 7,9 & 6,7 & 3,0 & 4,5 & 17,9 & 8,7 & 7,5 \\
\hline & Empresa & 23,7 & 13,3 & 18,2 & 33,3 & 10,7 & 19,6 & 22,0 \\
\hline & IES & 57,9 & 46,7 & 60,6 & 33,3 & 53,6 & 26,1 & 43,6 \\
\hline & Outra inst. ens. & 5,3 & 13,3 & 15,2 & 12,1 & 10,7 & 2,2 & 9,5 \\
\hline & Inst. pesq. & 5,3 & 16,7 & 3,0 & 16,7 & 3,6 & 43,5 & 16,6 \\
\hline & Inst. assessoria & & 3,3 & & & 3,6 & & 0,8 \\
\hline & Total & 100,0 & 100,0 & 100,0 & 100,0 & 100,0 & 100,0 & 100,0 \\
\hline \multirow{3}{*}{$\begin{array}{l}\text { Atividade } \\
\text { envolve } \\
\text { pesquisa }\end{array}$} & Não & 21,1 & 46,7 & 52,9 & 31,3 & 58,6 & 28,3 & 37,3 \\
\hline & Sim & 78,9 & 53,3 & 47,1 & 68,7 & 41,4 & 71,7 & 62,7 \\
\hline & Total & 100,0 & 100,0 & 100,0 & 100,0 & 100,0 & 100,0 & 100,0 \\
\hline \multirow{3}{*}{$\begin{array}{l}\text { É docente em } \\
\text { univresidade }\end{array}$} & Não & 47,4 & 53,3 & 40,6 & 77,3 & 50,0 & 78,3 & 61,7 \\
\hline & Sim & 52,6 & 46,7 & 59,4 & 22,7 & 50,0 & 21,7 & 38,3 \\
\hline & Total & 100,0 & 100,0 & 100,0 & 100,0 & 100,0 & 100,0 & 100,0 \\
\hline
\end{tabular}


Tabela 6b. Situação de estudo e trabalho atual dos doutores por universidade; percentuais

\begin{tabular}{|c|c|c|c|c|c|}
\hline & & \multicolumn{4}{|c|}{ Universidade do curso } \\
\hline & & UFMG & UFRJ & USP & Total \\
\hline \multirow{6}{*}{$\begin{array}{l}\text { Pós-graduação } \\
\text { após o doutorado }\end{array}$} & Não fez & 90,0 & 76,3 & 54,2 & 67,0 \\
\hline & Fazendo pós-dout. & 1,7 & 1,3 & 7,2 & 4,6 \\
\hline & Fez pós-dout. país & 1,7 & 5,0 & 13,3 & 8,8 \\
\hline & Fez pós-dout. exterior & 6,7 & 13,8 & 19,9 & 15,7 \\
\hline & Fez PG lato sensu & & 3,8 & 5,4 & 3,9 \\
\hline & Total & 100,0 & 100,0 & 100,0 & 100,0 \\
\hline \multirow[t]{5}{*}{ Trabalho } & Procura trabalho & 3,3 & 4,9 & 3,0 & 3,5 \\
\hline & Outra & 1,7 & 2,4 & 5,4 & 3,9 \\
\hline & Plena atividade & 95,0 & 91,5 & 91,1 & 91,9 \\
\hline & Parc./tot. afastado & & 1,2 & 0,6 & 0,6 \\
\hline & Total & 100,0 & 100,0 & 100,0 & 100,0 \\
\hline \multirow{4}{*}{$\begin{array}{l}\text { Atividade } \\
\text { remunerada }\end{array}$} & Emp. setor públ. & 91,1 & 93,3 & 79,2 & 85,3 \\
\hline & Emp. setor priv. & 7,1 & 5,3 & 18,8 & 13,0 \\
\hline & Outras & 1,8 & 1,3 & 1,9 & 1,8 \\
\hline & Total & 100,0 & 100,0 & 100,0 & 100,0 \\
\hline \multirow[t]{7}{*}{ Tipo de trabalho } & Admin. públ. & 1,8 & 2,7 & 2,6 & 2,5 \\
\hline & Empresa & 1,8 & 4,0 & 3,3 & 3,2 \\
\hline & IES & 91,2 & 81,3 & 74,8 & 79,9 \\
\hline & Outra inst. ens. & 1,8 & 2,7 & 2,0 & 2,1 \\
\hline & Inst. pesq. & 3,5 & 9,3 & 15,2 & 11,3 \\
\hline & Inst.assess./ polít. & & & 2,0 & 1,1 \\
\hline & Total & 100,0 & 100,0 & 100,0 & 100,0 \\
\hline \multirow{3}{*}{$\begin{array}{l}\text { Atividade } \\
\text { envolve } \\
\text { pesquisa }\end{array}$} & Não & 8,9 & 1,3 & 11,0 & 8,1 \\
\hline & Sim & 91,1 & 98,7 & 89,0 & 91,9 \\
\hline & Total & 100 & 100 & 100 & 100 \\
\hline \multirow{3}{*}{$\begin{array}{l}\text { É docente em } \\
\text { univresidade }\end{array}$} & Não & 10,7 & 25,3 & 24,2 & 21,8 \\
\hline & Sim & 89,3 & 74,7 & 75,8 & 78,2 \\
\hline & Total & 100,0 & 100,0 & 100,0 & 100,0 \\
\hline
\end{tabular}

verifica-se que, em média, a proporção dos entrevistados em plena atividade aumentou cerca de $50 \%$ no caso dos mestres e quase $80 \%$, entre os doutores. Ou seja, a conclusão do mestrado contribuiu moderadamente e a do doutorado, decididamente, para a inserção profissional dos entrevistados. No caso dos doutores, a proporção dos que se encontram em plena atividade é praticamente independente da instituição formadora; entre os mestres, é bastante diversificada, variando de menos de 50\%, na UFMG, a mais de $80 \%$, na UnB.

Há semelhanças e diferenças entre as características da atividade profissional dos mestres e doutores que se encontram em plena atividade. Tanto mestres como doutores trabalham preferencialmente no setor público, embora estes em maior proporção do que aqueles. Da mesma forma, a atividade profissional, para a maioria deles, envolve pesquisa, ainda que essa característica seja bem mais acentuada entre os doutores (mais de 90\%) do que entre os mestres (menos de 2/3). A percentagem dos que trabalham em institutos de pesquisa é, em ambos os casos, próxima de $15 \%$. Raros são proprietários ou trabalham como autônomos. Em contrapartida, menos de $40 \%$ dos mestres são docentes em IES, enquanto quase $80 \%$ dos doutores têm esta atividade. Quase 1/4 dos mestres trabalha em empresas; já entre os doutores o percentual correspondente é inferior a $5 \%$.

É interessante comparar os mestres e doutores cuja atividade profissional principal é vinculada a empresas. Dos 361 mestres en- trevistados, 53 encontram-se trabalhando em empresas, sendo 41 no ramo industrial. Quando da inscrição no mestrado, 46 dos entrevistados trabalhavam em empresas, sendo 36 no ramo industrial. Ou seja, a conclusão do mestrado contribuiu para aumentar o número dos que trabalhavam em empresas e indústrias. Entre os doutores, esses números são bem diferentes. Quando da inscrição, 19 dos 311 entrevistados trabalhavam em empresas, sendo 18 no ramo industrial. Agora, existem apenas 9 trabalhando em empresas, sendo 5 em indústrias. Ou seja, a conclusão do doutorado acarretou diminuição do número daqueles que trabalham em empresas e indústrias.

Um outro aspecto a considerar é a atividade de pesquisa dos mestres e doutores que trabalham em empresas. Dos 53 mestres trabalhando em empresas, 35 , ou seja $56 \%$, estão realizando pesquisas, percentual equivalente ao dos mestres vinculados a outras atividades profissionais. Se nos restringirmos a aqueles do ramo industrial, essa percentagem sobe para quase $80 \%$, correspondendo a 31 profissionais. No caso dos doutores, apenas 4 dos 9 que trabalham em empresas realizam pesquisa.

As observações feitas no parágrafo anterior sugerem um tema para discussão. A iniciativa privada, ainda que de forma incipiente, está desenvolvendo atividades de investigação científica ou tecnológica na área de Química e vem contratando mestres para realizar estas pesquisas. Entretanto, a despeito de o doutor, pelo menos 
em tese, ser melhor preparado para realizar pesquisas do que o mestre, o setor privado não emprega doutores e sim mestres. Uma possível explicação para essa pelo menos aparente contradição seria de ordem salarial: a remuneração que o setor privado estaria disposto a pagar a seus pesquisadores seria inferior àquela que os doutores poderiam obter na área acadêmica. Entretanto, a remuneração paga aos mestres, seja pelo setor privado como um todo, seja especificamente pelas empresas, é apenas cerca de $20 \%$ menor do que a remuneração que as IES oferecem para os doutores, como será ainda apresentado. Essa diferença não seria coberta pelas empresas/setor privado, caso considerassem o doutor um profissional mais adequado às suas necessidades?

Talvez uma hipótese mais provável para explicar este fato seria a natural inclinação dos doutores para a atividade acadêmica. Quase $80 \%$ deles foram fortemente motivados a procurar o curso pelo desejo de seguir ou aprimorar a carreira docente. Entre os mestres este percentual é pouco maior do que 50\%. Uma diferença considerável, que, no entanto, precisa ser vista com um pouco de cautela, uma vez que $30 \%$ dos doutores já eram docentes em IES, quando se inscreveram no curso. No caso dos mestres, menos de $10 \%$ estavam nesta situação. De qualquer forma, permanece a mesma indagação: se as empresas estivessem convencidas de que os doutores seriam profissionais mais adequados do que os mestres para desenvolver suas atividades de pesquisa, elas não estabeleceriam vantagens que as tornariam capazes de competir com a área acadêmica por estes profissionais ${ }^{43}$ ?

Há uma terceira alternativa para explicar esse aparente paradoxo, que não pode ser descartada. As empresas, sobretudo aquelas do ramo industrial, já começaram a perceber a importância de recrutar profissionais de Química com formação pós-graduada, mas ainda não se convenceram de que o doutor atenderia melhor às suas necessidades - inclusive as de pesquisa - do que o mestre.

\section{A TRAJETÓRIA: DE ONDE VIERAM E ONDE ESTÃO OS MESTRES E DOUTORES EM QUÍMICA}

Outra questão de interesse da pesquisa era identificar características da trajetória dos egressos após sua titulação: de onde vieram e para onde foram? A resposta à indagação indica que o destino predominante dos egressos é a academia, seja como atuação profissional, seja como continuidade de sua formação, conforme pode ser verificado analisando os dados da Tabela 7.
Quando da inscrição ao mestrado, mais da metade dos entrevistados era inativa. Cerca de 3/4 destes declararam que a essa época eram estudantes. Mais de $70 \%$ dos que não declararam ser então estudantes foram admitidos ao mestrado no máximo dois anos após concluírem a graduação. Ou seja, o grupo de inativos compunha-se essencialmente de estudantes, que imediatamente após terminarem a graduação decidiram prosseguir seus estudos no mestrado. Após a titulação, metade dos anteriormente inativos declararam vínculo profissional permanente, a maioria deles, que corresponde a cerca de $17 \%$ do universo de mestres entrevistados, no meio acadêmico ${ }^{44}$. Entre os ex-inativos, observa-se também um contingente não desprezível que passou a ocupar postos de trabalho no mercado. Os que permanecem como inativos, quase todos eles (90\%), são estudantes de doutorado. Há ainda um pequeno número de mestres que não eram inativos quando ingressaram no curso e que agora o são. Cerca de $80 \%$ deles são também estudantes de doutorado. Ou seja, a inatividade após a conclusão do mestrado não pode ser traduzida como desemprego e sim como opção de, imediatamente, prosseguir estudos no doutorado.

Entre os que se encontravam empregados quando se inscreveram para o mestrado, apenas $10 \%$ passaram a ter atividade diferente após a titulação, sendo que $8 \%$ migraram para a academia. Portanto, a conclusão do mestrado não reorienta de forma significativa trajetórias profissionais, mas tende a propiciar a inserção profissional na área acadêmica, em especial no caso daqueles que eram inativos quando foram admitidos ao curso.

Quando da inscrição ao doutorado, quase a metade dos entrevistados estavam inativos. Cerca de $90 \%$ destes declararam ser estudantes nessa época, ou seja, ainda se encontravam no mestrado. Os demais entrevistados, em sua quase totalidade, encontravam-se vinculados ao meio acadêmico. A proporção dos que tinham atividade no mercado ou no Estado, somados, não chegava a $10 \%$. Após a titulação, essa situação alterou-se. A percentagem de inativos reduziu-se a menos de $5 \%$. O mesmo percentual aplica-se à soma dos que atuam do mercado e no Estado. Mais de $90 \%$ dos doutores têm hoje vínculo profissional definido, quase todos eles no meio acadêmico. Entre a pequena parcela que permanece como inativo, há predominância absoluta dos que se titularam na USP ${ }^{45}$. Ou seja, a conclusão do doutorado reforça a orientação profissional daqueles que já se encontravam vinculados ao meio acadêmico e dirige para essa mesma área o exercício profissional daqueles que, quando se inscreveram no curso, estavam inativos.

Tabela 7. Mercado, estado ou academia - trajetória de mestres e doutores da inscrição à situação atual; percentuais

\begin{tabular}{|c|c|c|c|c|c|c|c|}
\hline & & \multicolumn{6}{|c|}{ Situação e locus laboral atualmente } \\
\hline & & Mercado & Estado & Academia & Inativo & Desempregado & Total \\
\hline \multicolumn{8}{|l|}{ a. Mestres } \\
\hline Situação e locus & Mercado & 6,1 & 0,3 & 5,5 & 3,2 & & 15,2 \\
\hline \multirow[t]{5}{*}{ laboral na inscrição } & Estado & 0,6 & 1,6 & 2,3 & 1,0 & & 5,5 \\
\hline & Academia & 1,6 & & 15,5 & 2,6 & & 19,7 \\
\hline & Inativo & 7,1 & 2,6 & 16,8 & 25,8 & 1,6 & 53,9 \\
\hline & Desempregado & 1,0 & 0,6 & 2,3 & 1,3 & 0,6 & 5,8 \\
\hline & Total & 16,5 & 5,2 & 42,3 & 33,9 & 2,3 & 100,0 \\
\hline \multicolumn{8}{|l|}{ b. Doutores } \\
\hline Situação e locus & Mercado & 1,4 & & 4,6 & & 0,4 & 6,4 \\
\hline \multirow[t]{5}{*}{ laboral na inscrição } & Estado & & 1,4 & 0,4 & & & 1,8 \\
\hline & Academia & & & 39,2 & 1,8 & 0,4 & 41,3 \\
\hline & Inativo & 1,4 & 0,7 & 41,3 & 2,1 & 3,2 & 48,8 \\
\hline & Desempregado & 0,4 & & 1,1 & 0,4 & & 1,8 \\
\hline & Total & 3,2 & 2,1 & 86,6 & 4,2 & 3,9 & 100,0 \\
\hline
\end{tabular}


Com relação ao setor de trabalho de mestres e doutores em Química, antes e depois da titulação, o que se observa é que o término da pós-graduação favorece amplamente a atuação no setor público, conclusão a que se pode chegar cotejando as Tabelas 4a e 6a e as Tabelas $4 \mathrm{~b}$ e $6 \mathrm{~b}$. Antes de iniciarem o mestrado, $44 \%$ dos mestres encontravam-se ativos profissionalmente, sendo $23 \%$ deles na área pública e $21 \%$, na área privada. Após a conclusão do curso, $68 \%$ deles têm vínculo profissional definido, sendo $42 \%$ no setor público e $26 \%$, no privado. $\mathrm{Ou}$ seja, enquanto a percentagem dos que atuam no setor público cresceu quase $100 \%$, no privado, o crescimento não chegou a 1/4 disso. Os números são da mesma magnitude, no caso do doutorado. Ao ingressarem no curso, $52 \%$ dos doutores eram ativos profissionalmente, sendo $41 \%$ na área pública e 11\%, na privada. Após a conclusão do doutorado, $93 \%$ passaram a ter vínculo profissional definido, sendo $79 \%$ no setor público e $14 \%$, no privado.

\section{QUANTO ESTÃO GANHANDO OS MESTRES E DOUTORES EM QUÍMICA?}

Solicitou-se aos entrevistados que declarassem sua renda pessoal, classificando-a em uma das seis faixas de valores em reais apresentadas. A menor faixa foi de até $\mathrm{R} \$ 1.500,00$ e a maior, superior a $\mathrm{R} \$ 5.500,00$. As rendas médias foram calculadas tomando-se o ponto médio do intervalo de valores que definiam a faixa. Para o caso das duas faixas extremas - superior e inferior - adotou-se o critério de manter constante, em $\mathrm{R} \$ 1.000,00$, a diferença entre a renda média de duas faixas subseqüentes.

A renda média ${ }^{46}$ declarada pelos mestres foi de aproximadamente $\mathrm{R} \$ 2.100,00$. Os mestres trabalhando em empresas recebem cerca de $20 \%$ acima dessa média e os que atuam em universidades ${ }^{47}, 5 \%$, conforme ilustra a Figura 4. Os mestres trabalhando em institutos de pesquisas recebem cerca de $20 \%$ menos do que aqueles vinculados às universidades. Os que trabalham no setor privado - que correspondem a cerca de $1 / 3$ dos que têm vínculo profissional - recebem aproximadamente $35 \%$ a mais do que os seus colegas do setor público. Praticamente não se observam diferenças de remuneração média, segundo a instituição formadora ${ }^{48}$. Apenas os que se formaram pela UFBA se destacam um pouco nesse aspecto, registrando renda $10 \%$ superior à média global.

A remuneração média dos doutores, da ordem de $\mathrm{R} \$ 3.000,00$, é cerca de $40 \%$ superior à dos mestres. A diferença de remuneração

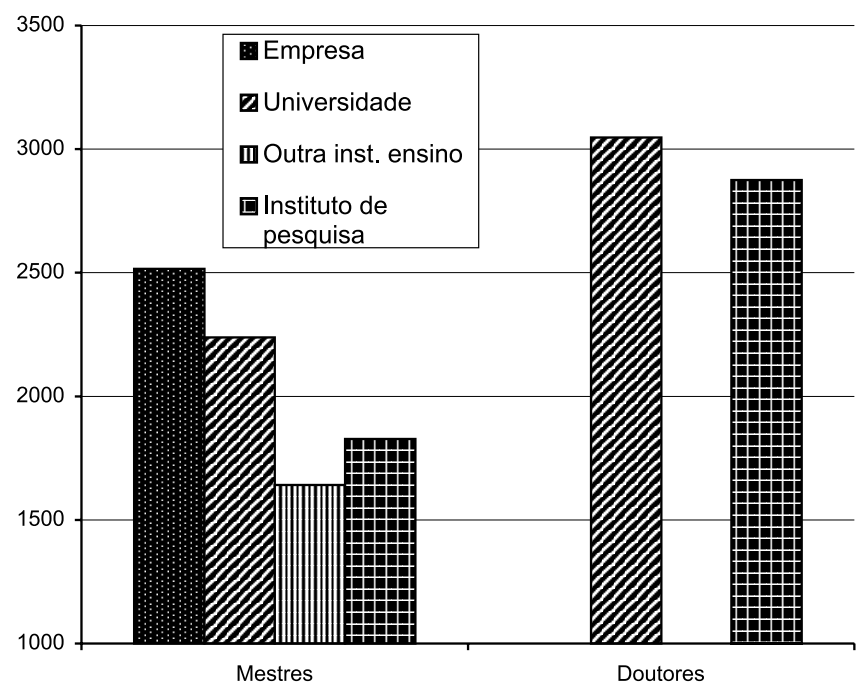

Figura 4. Médias de renda, em reais, por principais tipo de trabalho entre aqueles que trabalham em universidades e os que trabalham em institutos de pesquisa, que, juntos, correspondem a mais de $90 \%$ dos doutores com vínculo profissional, praticamente se anula, estando na faixa de 5\%, conforme ilustra a Figura 4. A remuneração dos que trabalham em empresas é mais de $1 / 3$ superior à média global, mas estes representam apenas $3 \%$ dos doutores com atividade profissional. Os que trabalham no setor privado - que correspondem a cerca de $15 \%$ dos que têm vínculo profissional - recebem aproximadamente $20 \%$ a mais do que os seus colegas do setor público. A diferença de remuneração entre doutores e mestres no setor público, $55 \%$, é maior do que no setor privado, $45 \%$.

No caso dos doutores, as diferenças de remuneração segundo a instituição formadora são mais pronunciadas do que o observado para os mestres. As remunerações dos titulados pela UFMG, aproximadamente $\mathrm{R} \$ 2.900,00$, e pela UFRJ, da ordem de $\mathrm{R} \$ 2.700,00$, diferem pouco entre si, menos de $10 \%$. Já os titulados pela USP declararam renda média de $\mathrm{R} \$ 3.300,00$, valor que é cerca de $20 \%$ superior ao verificado na média das duas universidades federais. Uma análise mais detalhada dos dados colhidos ${ }^{49}$ sugere que a maior remuneração dos doutores da USP está, aparentemente, associada a dois fatores. O primeiro deles, de menor importância, é a eventual diferença no padrão de remuneração das universidades estaduais paulistas e das universidades federais. O segundo, de relevância bem maior, é o número de oportunidades de atuação no ensino superior particular, cujo padrão de remuneração é cerca de $20 \%$ superior ao das universidades públicas, que parece ser bem maior em São Paulo do que no Rio de Janeiro ou em Minas Gerais ${ }^{50}$.

Como seria de se esperar, a remuneração cresce com a experiência profissional, tanto para mestres como para doutores. Em ambos os casos, esse aumento é aproximadamente linear ${ }^{51}$, crescimento este que é mais expressivo no caso dos mestres - da ordem de 5\% a cada ano - do que para os doutores - cerca de $3 \%$ a cada ano. Sendo assim, os mestres titulados em 90 recebem cerca de $35 \%$ a mais do que os que concluíram o curso em 97, enquanto que no caso dos doutores essa diferença não chega a $25 \%$.

Os homens têm renda cerca de $20 \%$ superior à das mulheres, tanto no caso dos mestres quanto dos doutores. Essa diferença não pode ser atribuída à experiência profissional, uma vez que tanto para os mestres, quanto para os doutores, o tempo de titulação médio de homens e mulheres é aproximadamente o mesmo. Ela existe tanto no setor público quanto no privado, embora neste último seja mais pronunciada do que no primeiro; também está presente em praticamente todos os tipos de atividades profissionais, inclusive entre os docentes do ensino superior, ainda que, para esses, seja bem menor inferior a $10 \%$ - entre os doutores. É também encontrada, de forma invariável, em todas as instituições formadoras, embora entre os mestres titulados pela USP seja bem pequena - inferior a $5 \%$.

Como se sabe, essa tendência, decorrente entre outras causas de uma discriminação velada em relação às mulheres no mercado de trabalho, repete-se - não apenas ao longo dessa pesquisa, mas também, ainda que de forma matizada - na esmagadora maioria das ocupações profissionais no Brasil. No entanto, ainda que de grande centralidade, o caráter marcadamente "machista" da nossa sociedade não é suficiente para explicar adequadamente as inúmeras particularidades e especificidades das relações de gênero no âmbito laboral. É o que ocorre em relação a essa pesquisa, uma vez que boa parte dos mestres e a quase totalidade dos doutores trabalham na área acadêmica e em instituições públicas, nas quais os padrões de remuneração das carreiras são bem definidos e praticamente imunes às diferenças de sexo. Portanto, é surpreendente a constância com que se observou a maior remuneração dos homens, em praticamente todas as comparações feitas. Não foi possível encontrar um fator específico que pudesse representar uma explicação plausível para essa regu- 
laridade, com os dados colhidos na pesquisa. Certamente, pode-se imaginar diversas razões que contribuiriam para isso, mas todas elas são de natureza subjetiva e impossíveis de ser comprovadas com as informações de que dispomos ${ }^{52}$.

\section{CONTRIBUIÇÕES DO MESTRADO PARA O TRABALHO ATUAL}

Uma questão-chave da pesquisa referia-se às relações entre a formação recebida e o trabalho que desenvolviam na época em que foram coletados os dados. Que contribuições teve o curso para o trabalho atual, segundo a percepção dos egressos? As experiências de trabalho após o curso correspondem às expectativas da época da inscrição? Foram apresentados aos entrevistados quatro quesitos para serem avaliados, conforme a contribuição que estariam tendo para o seu exercício profissional atual: formação teórica, experiência em pesquisa, atualização/reciclagem de conhecimentos e contatos acadêmicos e profissionais. A súmula das respostas a essas questões encontra-se registrada nas Figuras 5 a e 5b, sendo discriminadas conforme o tipo de trabalho atual do entrevistado, com registro apenas para aquelas atividades que congregam mais de $10 \%$ dos mestres ou dos doutores.

Mestres e doutores avaliam a sua formação na pós-graduação de forma extremamente positiva. A experiência em pesquisa é o fator que mais é citado como estando contribuindo muito para o exercício profissional: assim opinam mais de $80 \%$ dos mestres e mais de $90 \%$ dos doutores. Esses percentuais pouco são afetados pelo tipo de instituição a que o entrevistado está profissionalmente vinculado. Em qualquer caso, este é o fator mais citado como "está contribuindo muito". A resposta a esse quesito é compatível com a motivação para a pós-graduação. Como vimos, a procura pela pós-graduação foi motivada, sobretudo, pelo desejo de seguir carreira de pesquisador.

A formação teórica é também avaliada de forma muito favorável: quase $3 / 4$ dos mestres e mais de $80 \%$ dos doutores consideram que ela está contribuindo muito para o seu exercício profissional. Como se observa nas Figuras 5 a e 5b, os que são docentes do ensino superior são os que mais valor atribuem à formação teórica. Os que trabalham em empresas ou em outras instituições de ensino são os que menos a consideraram importante. Ainda assim, mais de $60 \%$ destes classificaram-na como estando contribuindo muito para o exercício profissional.

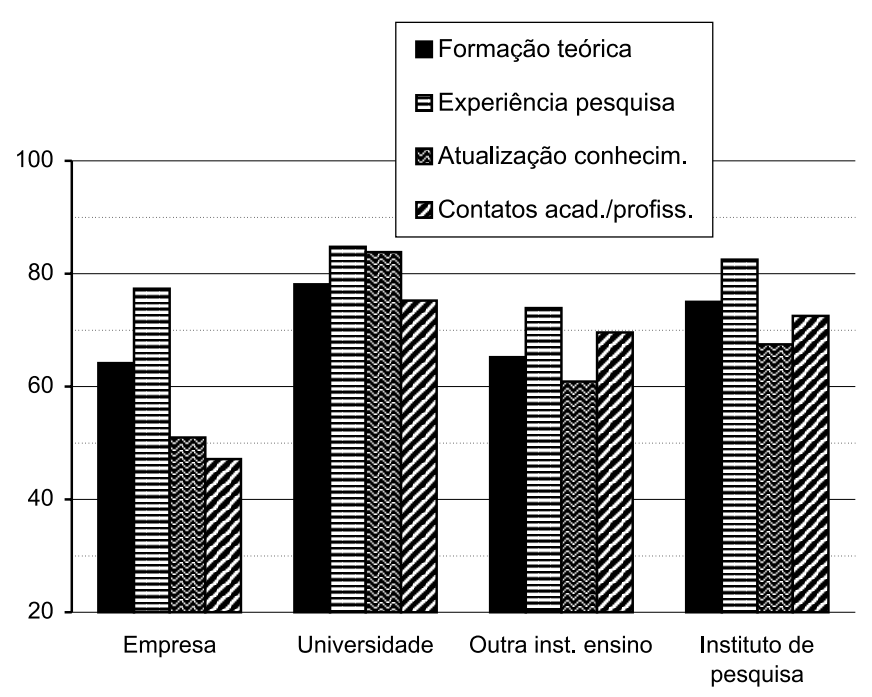

Figura 5a. Contribuições do mestrado para os principais tipos de trabalho; percentual de "contribuiu muito"
Entre os mestres, aqueles atuando em empresas não avaliam de forma tão positiva a atualização de conhecimentos e os contatos acadêmicos e profissionais. Esses dois fatores foram, entretanto, considerados de forma muito favorável pelos mestres que são docentes do ensino superior e, em percentual um pouco menor, pelos que são docentes de outras instituições de ensino ou que trabalham em institutos de pesquisa. No caso dos doutores, as diferenças de avaliação entre os professores universitários e os pesquisadores de institutos de pesquisa é irrelevante, em relação a qualquer um dos quesitos.

\section{O IMPACTO DA PÓS-GRADUAÇÃO NA VIDA PROFISSIONAL: O QUE MUDA DEPOIS?}

Indagou-se também se a formação no mestrado e no doutorado trouxe mudanças em alguns aspectos relevantes do trabalho dos egressos, comparando-se sua situação antes e depois do curso, procurando-se avaliar se ocorreram alterações e, em caso positivo, em que medida estas atenderam às expectativas que tinham os egressos quando se inscreveram. Os resultados encontrados ${ }^{53}$ estão apresentados nas Figuras 6a e 6b.

O que se pode observar é que a formação recebida na pós-graduação, tanto no caso dos mestres como dos doutores, atendeu plenamente às expectativas dos entrevistados, avaliação que é mais ou menos uniforme, independentemente do tipo de trabalho desenvolvido atualmente. Quando se soma o percentual daqueles que avaliaram a contribuição do curso como estando "dentro do esperado" com o daqueles que a julgaram "acima do esperado", encontram-se, em todos os casos, valores superiores a $80 \%$ e, na maioria deles, acima mesmo de $90 \%$. Trata-se, portanto, de um quadro de elevada satisfação com a formação recebida.

\section{CONCLUSÕES}

Os mestres e doutores em Química são egressos preferencialmente de cursos de graduação na área de Química, mas cerca de $30 \%$ deles, em ambos os níveis, advém de áreas conexas da graduação, característica que é bem mais acentuada para os titulados pela

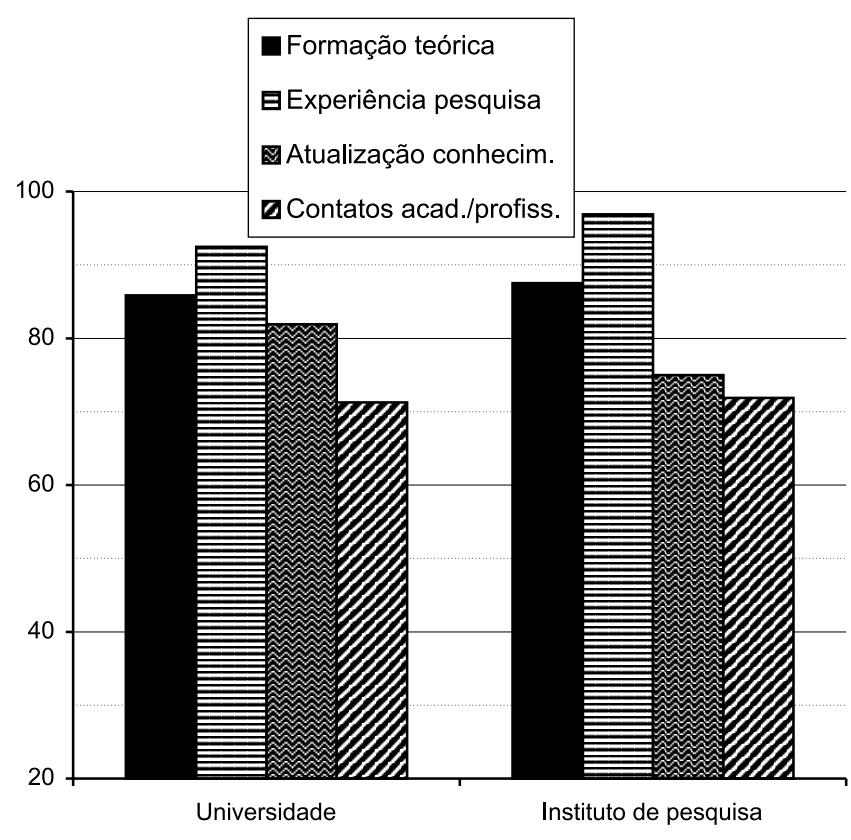

Figura 5b. Contribuições do doutorado para os principais tipos de trabalho; percentual de "contribuiu muito" 


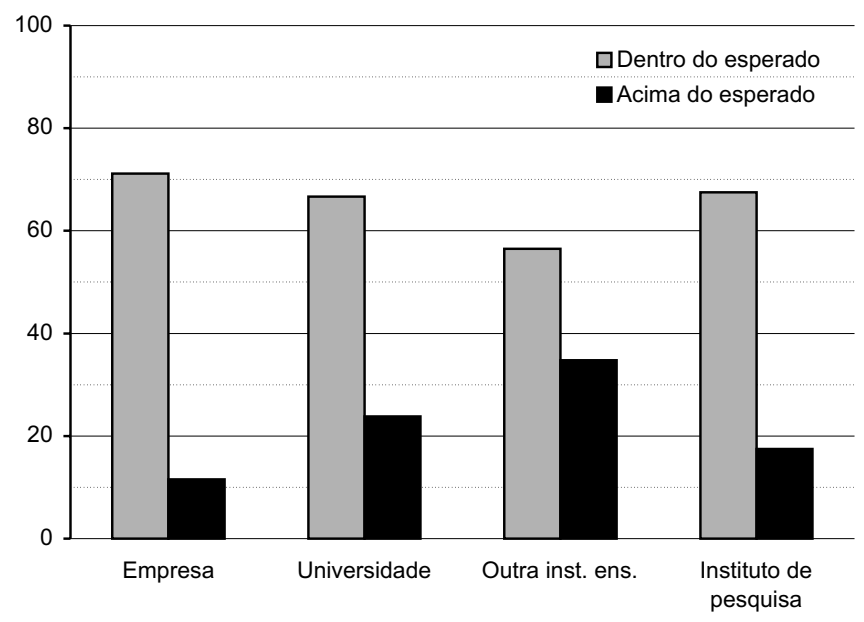

Figura 6a. Aumento da competitividade profissional ou acadêmica dos mestres após a titulação; percentuais

UFRJ, para os quais os percentuais correspondentes aproximam-se de $60 \%$. Entre os mestres, há preponderância do sexo feminino; entre os doutores, homens e mulheres encontram-se em proporção eqüitativa. Tais resultados sugerem que a procura feminina pela área está aumentando.

A idade média de graduação observada foi de 24,1 anos, para os mestres, e de 23,7 anos, para os doutores. Ainda que essa diferença seja pequena, ela sinaliza para uma tendência que é confirmada por outros indicadores: a idade de graduação aumentou, no período correspondente a este estudo. Esse aumento é nítido no caso dos doutores, mas não é observado entre os mestres. Ou seja, essa idade aumentou para aqueles que se graduaram na década de 80 , tendo permanecido nesse patamar mais elevado na década seguinte.

O ingresso no mestrado ocorre cerca de 3 anos após a graduação, mas esta média apresenta grande dispersão, o que caracteriza a coexistência de trajetórias diferentes. Cerca de $2 / 3$ dos titulados foram admitidos no curso até dois anos após se graduarem. Mas, aproximadamente $20 \%$ deles foram admitidos ao mestrado muitos anos após se graduarem, em um período que varia de 6 a 25 anos. O ingresso no doutorado ocorre em média quase 7 anos após a graduação, observando-se dois grupos bem diferenciados em relação a esse aspecto. Aqueles que fizeram anteriormente o mestrado - que correspondem a 3/4 dos entrevistados - ingressam no doutorado praticamente em seguida à conclusão do mestrado, salvo poucas exceções. Os que foram direto para o doutorado o fazem geralmente logo após concluírem a graduação.

A duração média do mestrado é de 3,3 anos, valor que decresceu expressivamente ao longo da década, variando de mais de 4 anos, em 1990, para menos de 3 anos, em 1997, fato que certamente decorre das políticas acadêmicas induzidas pelas agências de fomento, notadamente CAPES e CNPq. No caso do doutorado, a duração do curso é de cerca de 5 anos, valor que permaneceu mais ou menos o mesmo, ao longo das coortes estudadas. À primeira vista, essa constatação sugere que a duração do doutorado teria alcançado um valor compatível com as condições para o desenvolvimento da pesquisa científica, nessa área, nas instituições pesquisadas. No entanto, um olhar mais acurado dos dados colhidos, descartando-se os casos de duração excessiva do doutorado e considerando que eles não se repetirão para as próximas coortes, indica uma possível redução do tempo médio de doutoramento nas universidades consideradas neste estudo.

A idade média de titulação é de 31 anos, para o mestrado, e de 36 anos, para o doutorado. Esses valores são muito elevados, quan-

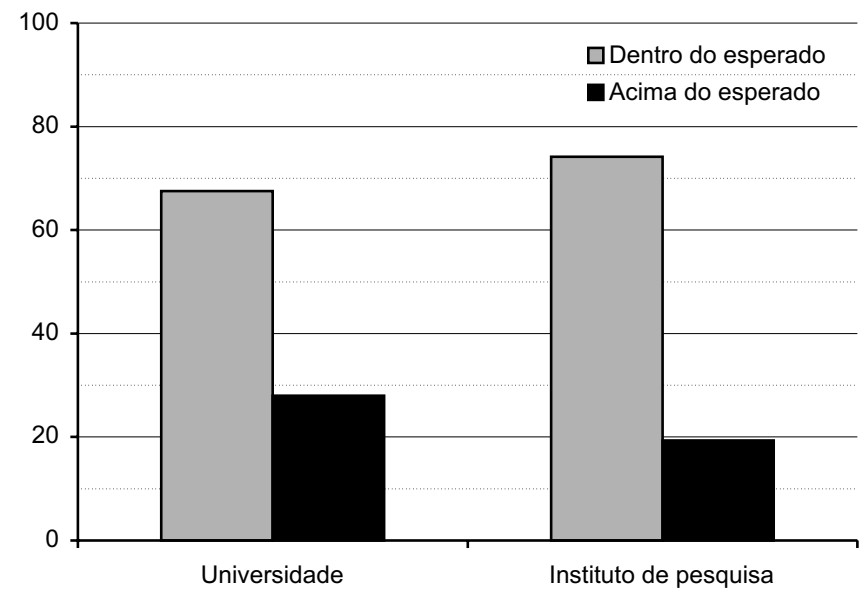

Figura 6b. Aumento da competitividade profissional ou acadêmica dos doutores após a titulação; percentuais

do comparados aos parâmetros internacionais, que indicam idade média de doutoramento de 28 anos, tanto nos EUA, como na Europa ocidental. Entre os doutores, aqueles que vão diretamente da graduação para o doutorado titulam-se bem mais jovens (33,9 anos) do que os seus demais colegas (36,5 anos). A idade de titulação dos mestres apresentou tendência de decréscimo no período estudado e a dos doutores, de acréscimo. Os dados colhidos permitem ainda projetar que, para as próximas coortes, a idade média de doutoramento, na melhor das hipóteses, se estabilizará em um valor próximo de 37 anos.

A maior parte de mestres e doutores era estudante, de graduação ou de mestrado, quando se inscreveu na pós-graduação. Tanto no caso dos mestres como dos doutores, a fração dos que tinham vínculo profissional à essa época era de $40 \%$. Entre os mestres, esse vínculo profissional ocorria, em proporções mais ou menos eqüitativas, nos setores público e privado e a fração dos que exerciam o magistério superior não superava 1/5. Entre os doutores, quase todos estavam vinculados ao setor público e a grande maioria era docente do ensino superior. A atividade de pesquisa se associava ao trabalho da maioria dos mestres e doutores que, a essa época, exerciam atividades profissionais, sendo em freqüência maior para os últimos do que para os primeiros.

A motivação para a pós-graduação decorre basicamente do desejo de seguir ou aprimorar carreiras de pesquisador ou de docente. A maioria - e às vezes a grande maioria - dos entrevistados considerou que esses fatores foram muito importantes para a sua opção. Os percentuais correspondentes são maiores no caso dos doutores. A vontade de seguir carreira de pesquisador contribuiu mais do que a de seguir carreira docente, especialmente entre os doutores. Exerce também forte influência o desejo de ampliar as oportunidades profissionais e o de obter um melhor trabalho em termos acadêmicos e profissionais.

Após a titulação, os mestres tendem a imediatamente se inscrever no doutorado. Quase 60\% dos entrevistados já estavam vinculados a programas de doutoramento, percentual que se aplica mesmo para as coortes mais recentes. Cerca de $2 / 3$ dos mestres relataram atividade profissional plena após a titulação, o que revela que a conclusão do mestrado contribui medianamente para a inserção profissional na área. Essa atividade profissional está sendo realizada preferencialmente no setor público e geralmente envolve atividades de pesquisa. Cerca de $40 \%$ são docentes do ensino superior e quase $1 / 4$ trabalha em empresas, a maioria deles em atividades industriais. 
No caso dos doutores, a titulação contribui decididamente para a inserção profissional. Mais de $90 \%$ deles declararam estar em plena atividade profissional, quase toda ela exercida no setor público, na área acadêmica e, com raras exceções, envolvendo a realização de pesquisas. São poucos os que trabalham em empresas e raríssimos os que atuam no ramo industrial. A fração de doutores que já realizou, ou está realizando, estágios de pós-doutoramento é da ordem de 1/3.

Os mestres em Química recebem em média cerca de $\mathrm{R} \$ 2,1$ mil mensais. Os que atuam em empresas e em universidades têm rendimentos um pouco maior do que esse valor, com acréscimos de, respectivamente, $20 \%$ e $5 \%$. Os que trabalham em institutos de pesquisa recebem cerca de $20 \%$ menos dos que os docentes do ensino superior. O setor privado remunera cerca de $35 \%$ melhor do que o público.

A remuneração média dos doutores é de $\mathrm{R} \$ 3,0$ mil mensais e é praticamente a mesma para os que trabalham em universidade e em instituto de pesquisa. Os raros doutores trabalhando em empresas recebem cerca de $30 \%$ acima da média global. O setor privado remunera cerca de $20 \%$ melhor do que o público.

Tanto no caso dos mestres como no dos doutores, a remuneração tende a crescer com a experiência profissional, de forma aproximadamente linear. $\mathrm{O}$ aumento médio por ano de experiência é de cerca de $\mathrm{R} \$ 120,00$, no caso dos mestres e de cerca de $\mathrm{R} \$ 85,00$, no caso dos doutores. Também nos dois níveis, verifica-se que a remuneração dos homens é superior à das mulheres, em cerca de $20 \%$, regularidade observada, tanto no setor público, quanto no privado, em quase todo tipo de atividade profissional e qualquer que seja a instituição formadora.

Foram apresentadas aos entrevistados diversas características da formação acadêmica, solicitando-lhes que indicassem aquelas que estão contribuindo para a sua atividade profissional, a saber: formação teórica, experiência em pesquisa, reciclagem de conhecimentos e possibilidade de contatos acadêmicos e profissionais. Tanto mestres como doutores fazem uma avaliação muito positiva de todos os quesitos, especialmente da experiência em pesquisa e da formação teórica, a primeira com melhores índices do que a segunda. As diferenças observadas nessa avaliação, conforme o tipo de trabalho atual, são pouco expressivas, seja no caso dos mestres e, principalmente, no dos doutores.

No que se refere ao aumento da competitividade profissional com a titulação, mestres e doutores manifestaram elevado grau de satisfação. No primeiro caso, a soma dos que consideraram que o curso atendeu às expectativas com os que julgaram que as expectativas foram superadas alcança mais de $80 \%$, independentemente do tipo de trabalho atual. Os doutores são ainda mais otimistas em relação a esse aspecto e o percentual correspondente ultrapassa $90 \%$.

\section{AGRADECIMENTOS}

Os autores agradecem à CAPES e à UNESCO, pelo apoio financeiro e suporte indispensáveis para a realização do projeto, e aos colegas e amigos J. Velloso, H. Sampaio, M. do C. de L. Peixoto e T. F. Bogutchi pelas valiosas sugestões e apoio à redação deste texto.

\section{REFERÊNCIAS E NOTAS}

1. Reheinbold, H. Em As Ciências no Brasil; Azevedo, F., org.; $2^{\mathrm{a}}$ ed., Ed. UFRJ: Rio de Janeiro, 1994, v. II , cap. 8.

2. Mathias, S. Em A História das Ciências no Brasil; Ferri, M.G; Motoyama, S., orgs.; Ed. da USP: São Paulo, 1979, v. I, cap. 4.

3. Filgueiras, C. A. L.; Quim. Nova 1986, 9, 263; Filgueiras, C. A. L.; Quim. Nova 1988, 11, 210.

4. Schwartzman, S.;Formação da Comunidade Científica no Brasil, Ed. Nacional: São Paulo, 1979, cap. 7 e 9.
5. Nesse período, diversos líderes estudantis foram arbitrariamente expulsos das universidades e/ou presos, sendo que muitos deles foram obrigados a buscar asilo político em outros países. Do mesmo modo, inúmeros professores, além das aludidas violências, foram aposentados compulsoriamente e tiveram seus direitos políticos suspensos. Ainda que em menor grau, ocorreram também casos de assassinatos, pelos órgãos da repressão política, de estudantes e professores. Entre os "desaparecidos" políticos desse período encontra-se a Profa. Ana Rosa Kucinsci, do IQ USP (ver ref. 6). Entre 1964 e 1973, 257 professores e intelectuais foram expurgados da burocracia estatal brasileira (ver ref. 7).

6. Miranda, N.; Tibúrcio, C.; Dos Filhos deste Solo, Ed. Fundação Perseu Ábramo, Boitempo Editorial: São Paulo, 1999.

7. Morel, R. L. M.; Ciência e Estado: A Política Científica no Brasil, T. A. Queiroz: São Paulo, 1979.

8. Brasil; Avaliação da pós-graduação: síntese dos resultados, 1981-1993, CAPES: Brasília, 1996; Brasil; Avaliação da pós-graduação - 1996: síntese dos resultados, CAPES: Brasília, 1996.

9. Brocksom, T. J.; Andrade, J. B. de; Quim. Nova 1997, 20 (Especial), 29.

10. Ferraz, H. M. C.; Pardini, V. L.; Quim. Nova 1997, 20 (Especial), 75.

11. Yoshida, M.; Andrade, J. B. de; Braz Filho, R.; Brocksom, T. J.; Coelho, A.; Nome, F.; Vichi, E. J. S.; Quim. Nova 1991, 14, 306; Andrade J. B. de; Schor, H. H. R.; Nascimento, M. A. C. do; Giordan, M.; Brocksom, T. J.; Aguilera, F. J. N.; Barreiro, E. J.; Quim. Nova 1995, 18, 97; Gama, A. A. S. da; Nome, F. J.; Machado, J. C.; Quim. Nova 1999, 22, 443.

12. Cagnin, M. A. H.; Quim. Nova 1988, 11, 478.

13. Esta pesquisa considerou, em seu conjunto, treze programas de pósgraduação em Química, tendo em vista que na UFRJ e na USP os programas são organizados por sub-áreas da Química. Desses, três foram classificados como 6, sete, como 5, e dois, como 4, na avaliação da CAPES referente ao biênio 96/97. Apenas dois desses treze programas começaram a funcionar após 1980.

14. Velloso, J., org.; A pós-graduação no Brasil: formação e trabalho de mestres e doutores no país, v. I: Administração, Agronomia, Bioquímica, Clínica Médica, Engenharia Civil, Engenharia Elétrica, Física, Química e Sociologia, CAPES/UNESCO: Brasília, 2002.

15. O projeto foi coordenado pelo Prof. Jacques Velloso, da UnB.

16. Foi usado o pacote estatístico conhecido pela sigla SPSS.

17. Dos 361 mestres entrevistados, $28 \%$ foram titulados pela UFRJ; $17 \%$ pela USP; $16 \%$ pela UFMG; $15 \%$ pela UFRGS; $14 \%$ pela UFBA e $10 \%$ pela UnB.

18. Foram entrevistados nesta pesquisa 311 doutores, sendo $54 \%$ titulados pela USP, $26 \%$, pela UFRJ e $20 \%$, pela UFMG.

19. Essa diferença de comportamento observada entre a UFRJ e as demais universidades, em especial quando comparada à USP, sugere que este fator possa ser objeto de análises mais detalhadas no futuro, visando compreender as razões que o motivam.

20. Velloso, J.; Velho, L.; Mestrandos e doutorandos no país: trajetórias de formação, CAPES: Brasília, 2001.

21. Braga, M. M.; Miranda-Pinto, C. O. B.; Cardeal, Z. L.; Quim. Nova 1997, 20, 438; Braga, M. M.; Peixoto, M. C. L.; Carvalho, M. G. M.; Avaliação, Revista da Rede de Avaliação Institucional da Educação Superior 1999, 4, 67.

22. Não se observam diferenças expressivas nesta média entre as instituições consideradas; ela varia entre 23,7 anos para os titulados pela UnB e 24,6 anos, no caso da UFBA.

23. Este valor é praticamente o mesmo na UFMG, UFRJ e USP.

24. Para quase todas as instituições pesquisadas, o tempo médio decorrido entre a conclusão da graduação e o ingresso no mestrado é de cerca de 3,0 anos, exceto na UFBA, onde se aproxima de 4,0 anos e na UnB, onde supera esta marca.

25. As diferenças observadas em relação a essa média entre UFMG, USP e UFRJ não são significativas.

26. Deve ser mencionado que a metodologia empregada nesta pesquisa, para calcular diferenças de tempos, maximiza o resultado. Solicitou-se, por exemplo, aos entrevistados que declarassem o ano em que concluíram a graduação e o de início da pós-graduação, calculando-se o interregno por diferença. Dessa forma, para aquele que se graduou em dezembro de 1992 e iniciou a pós em março de 1993, associou-se o tempo de um ano para o interregno entre esses dois eventos.

27. Muitas das informações colhidas nesta pesquisa não estão sendo apresentadas em gráficos ou tabelas evitando-se, dessa forma, tornar este texto longo e sua leitura enfadonha. No entanto, muitas vezes será necessário recorrer a essas informações não descritas em tabelas ou gráficos, para suportar análises e hipóteses feitas. É o que ocorre nesse parágrafo e se repetirá diversas outras vezes.

28. Mais de $60 \%$ dos doutores que cursaram anteriormente o mestrado registram um tempo máximo de um ano entre a conclusão do mestrado e o ingresso no doutorado. 
29. Metade deles relata ter sido admitida no doutorado até 2 anos após concluir a graduação.

30. Quase 3/4 deles eram docentes do ensino superior, quando se inscreveram para o doutorado.

31. Esses dois conjuntos de coortes têm praticamente a mesma população.

32. A duração do mestrado não varia muito entre as instituições formadoras, exceto no caso da UnB, com um valor bem abaixo da média geral, 2,5 anos, e da UFBA, que é um pouco acima desta, 3,7 anos.

33. Essa média varia muito entre as instituições pesquisadas: UFRJ, 4,7 anos; USP, 5,1 anos e UFMG, 5,6 anos.

34. Como a política da CAPES induzindo uma maior eficiência na formação foi desenvolvida tanto para o mestrado como para o doutorado, o fato de que resultados foram obtidos em relação ao mestrado, mas não para o doutorado, apontaria para essa conclusão.

35. Ou seja, todos aqueles admitidos no doutorado a partir de 1988, inclusive, considerando uma duração mínima de 3 anos para o doutorado.

36. Para os doutores também graduados em Química, a duração média do curso é de 5,3 anos, enquanto que para os graduados em outras áreas é de 4,7 anos. Para os mestres, essas mesmas médias são de respectivamente 3,4 anos e 3,1 anos.

37. As diferenças mais expressivas neste caso são observadas para os titulados pela USP.

38. Braga, M. M.; Peixoto, M. C. L.; Bogutchi, T. F.; Cadernos de Pesquisa 2001, 113, 129 .

39. Mangematin, V.; Research Policy 2000, 29, 741.

40. Na realidade, mesmo para estes, a idade média de titulação vem aumentando, tendo passado de 33 anos, para o conjunto das coortes de 90 a 94, que incluem 40 desses doutores, para 35 anos, para o conjunto das coortes de 95 a 97, que incluem 31 desses doutores, o que agrava a situação descrita.

41. Mais de $75 \%$ dos mestres e quase $90 \%$ dos doutores que declararam estar em outra situação de trabalho informaram também que eram estudantes. Entre os que informaram não ser estudantes a essa época, grande parte declarou um tempo máximo de um ano entre a conclusão da formação anterior e o ingresso no novo curso.

42. No contexto global da pesquisa, os piores rendimentos estão sendo auferidos pelos pós-graduados em Química, cuja renda média é a menor no caso dos doutores e, ao lado dos físicos, também a menor, no caso dos mestres. Em ambos os casos, ela é cerca de $50 \%$ menor do que a média salarial dos titulados em Administração e Clínica Médica e $30 \%$ inferior à dos titulados em Engenharia ou Sociologia (ver Ref. 14).
43. Os poucos doutores trabalhando em empresas têm um padrão salarial cerca de $30 \%$ superior ao dos vinculados às IES.

44. Neste trabalho foram classificados como pertencentes à academia os profissionais vinculados ao ensino superior e aos institutos de pesquisa.

45. A composição dos atualmente inativos é a seguinte, conforme a instituição formadora: UFMG, $8 \%$, UFRJ, $17 \%$ e USP, $75 \%$.

46. Para o cálculo das médias salariais, foram excluídos os mestres e doutores que não desenvolvem atividade profissional atualmente, inclusive aqueles mestres que recebem bolsa de doutorado.

47. Foram incluídos nessa categoria todos aqueles que são docentes no ensino superior.

48. Os valores observados foram os seguintes, em números aproximados: UFBA, R\$ 2.300,00, UnB, R\$ 2.200,00, UFMG, UFRGS e USP, R\$ $2.100,00$ e UFRJ, R\$2.050,00.

49. Essa análise teve em conta que os doutores em Química, em sua maioria, residem na mesma cidade em que se titularam, que cerca de $90 \%$ deles atuam na área acadêmica e considerou, ainda, a variação da renda segundo a dependência administrativa — federal, estadual ou particular — da atividade profissional atual do entrevistado.

50. Quase $20 \%$ dos doutores titulados pela USP que são docentes do ensino superior atuam na rede privada. Esse percentual não chega a 5\%, no caso dos titulados pela UFMG e pela UFRJ, em seu conjunto.

51. Os coeficientes de correlação linear correspondentes foram de 0,9 , para o caso dos mestres, e de 0,8 , para os doutores.

52. Por exemplo, embora tendo tempo de titulação comparável ao dos homens, as mulheres podem ter menor tempo de serviço do que os homens. $\mathrm{Ou}$ ocupar, em menor proporção, cargos de chefia. Ou, as mulheres têm ganho menor na prestação de serviços das instituições públicas de ensino superior. $\mathrm{Ou}$, ainda, as mulheres tendem a subestimar sua renda e os homens, a superestimá-la.

53. Deve-se ressaltar que estão computadas apenas as respostas dos que declararam vínculo profissional atual, quer estejam em plena atividade ou afastados. O que, como visto, corresponde a cerca de $2 / 3$ dos mestres e a mais de $90 \%$ dos doutores. 